IZA DP No. 6616

Labor Force Participation of Married Women in Turkey: Is There an Added or a Discouraged Worker Effect?

Deniz Karaoglan

Cagla Okten

June 2012 


\title{
Labor Force Participation of Married Women in Turkey: Is There an Added or a Discouraged Worker Effect?
}

\author{
Deniz Karaoglan \\ METU \\ Cagla Okten \\ Bilkent University \\ and IZA \\ Discussion Paper No. 6616 \\ June 2012 \\ IZA \\ P.O. Box 7240 \\ 53072 Bonn \\ Germany \\ Phone: +49-228-3894-0 \\ Fax: +49-228-3894-180 \\ E-mail: iza@iza.org
}

Any opinions expressed here are those of the author(s) and not those of IZA. Research published in this series may include views on policy, but the institute itself takes no institutional policy positions.

The Institute for the Study of Labor (IZA) in Bonn is a local and virtual international research center and a place of communication between science, politics and business. IZA is an independent nonprofit organization supported by Deutsche Post Foundation. The center is associated with the University of Bonn and offers a stimulating research environment through its international network, workshops and conferences, data service, project support, research visits and doctoral program. IZA engages in (i) original and internationally competitive research in all fields of labor economics, (ii) development of policy concepts, and (iii) dissemination of research results and concepts to the interested public.

IZA Discussion Papers often represent preliminary work and are circulated to encourage discussion. Citation of such a paper should account for its provisional character. A revised version may be available directly from the author. 


\section{ABSTRACT}

\section{Labor Force Participation of Married Women in Turkey: Is There an Added or a Discouraged Worker Effect?}

This article analyzes married women's labor supply responses to their husbands' job loss (added worker effect) and worsening of unemployment conditions (discouraged worker effect). We find that married women whose husbands are unemployed or underemployed are more likely to participate in the labor force and work more hours using yearly cross-sectional data from Turkey for the 2000-2010 period. We also construct two year panels based on questions on previous year's labor market outcomes. Panel results provide further support for the added worker effect. Wives whose husbands experience a job loss are more likely to increase their labor force participation. However, a worsening of overall unemployment conditions appears to have a discouraging effect on wives' labor supply response, wives tend to decrease their labor participation when unemployment rate in their region increases.

\section{NON-TECHNICAL SUMMARY}

Female labor participation in Turkey is much lower than the average in OECD where Turkey is also a member. Women's traditional role as a mother and a home maker is the most likely culprit for low participation rates. This article begins to ask how incentives might challenge this traditional role. Do married women whose husbands lose their jobs start looking for work? The answer is an unequivocal yes. Furthermore they are not likely to be discouraged by high unemployment rates. Are women who are more educated more likely to join the labor force? The answer is again a definite yes. University educated wives have an increased labor force participation probability of more than forty percent over only high school educated wives.

JEL Classification: J21, J60

Keywords: female labor force participation, added worker effect, Turkey

Corresponding author:

Cagla Okten

Department of Economics

Bilkent University

Bilkent, Ankara

Turkey

E-mail: cokten@bilkent.edu.tr 


\section{Introduction}

Greater equality between men and women is associated with poverty reduction, higher gross domestic product and better governance (World Bank 2001; Klasen 2002). Female labor force participation as an instrument for increased rights and better economic conditions for women can play an important role in achieving these development goals. In many developing countries, female labor force participation (LFP) remains to be low. In Turkey, married female LFP rate was 23.5 percent in 2009 , a significantly lower rate than the OECD country average rate of 64 percent (World Bank Report 48508-TR). ${ }^{1}$

Models of family labor supply show that unemployment of one spouse should increase the labor supply response of the other spouse (Ashenfelter, 1980). ${ }^{2}$ This has been called the added worker effect (AWE) where a married woman responds to the unemployment of her husband by increasing her labor supply. However, the empirical studies on developed countries find little evidence supporting the added worker effect (Cullen and Gruber (2000), Lundberg (1985), Maloney (1987, 1991), Prieto-Rodriguez and Rodriguez-Gutierrez (2003), Spletzer (1997)). Stephens (2002) and Kohara (2010) are the two exceptions where added worker effect is found to be significant and important using panel data from US and Japan respectively. This phenomenon has rarely been investigated in the context of developing countries. In this article we analyze the labor force participation decision of married women and the added worker effect using yearly cross-sectional data from the nationally representative Turkish Household Labor Force Surveys for the 2000-2010 period.

\footnotetext{
${ }^{1}$ Our focus is urban married women whose husbands are in the labor force. In our sample LFP rate of married urban women is $21 \%$ in 2009.

${ }^{2}$ In the model, he suggests that a decrease in the employment of a family member tends to raise the labor supply of family members if their non-market time is substitutable with that family member.
} 
In a static model of household labor supply AWE can occur for two reasons: 1) the husband's unemployment reduces household income (the income effect) and 2) the husband's time replaces the wife's time in household activities (the substitution effect).

If there are perfect capital markets, in a life cycle context wife's labor supply decision will take into account the present value of family wealth over the lifetime and not only current family income (Heckman and MaCurdy, 1980). Hence in developed countries, one reason for small or insignificant empirical findings for AWE could be the absence of liquidity constraints. ${ }^{3}$

It is well established that market opportunities for dealing with unemployment risk whether through insurance or through credit are less well developed in low income countries (Besley, 1995). Hence AWE might be more relevant in the context of developing countries.

The few studies from developing countries that exist, present mixed results. Felicio and Fernandes (2005) find that AWE is highly significant in Brazil, a middle income developing country, using a monthly employment survey of six metropolitan areas for the years 1985, 1993 and 1999. In contrast, Serneels (2002) find that AWE is not significant in Ethiopia---a low income developing country. Serneels (2002) concludes that households try other ways to deal with unemployment such as consumption smoothing or selling assets. ${ }^{4}$

In addition to unemployment status, we also consider the effect of underemployment of the husband on labor force participation of the wife. Underemployment is a more important issue for developing economies than it is for high income countries. Ours is the first study on a developing country that analyzes the effect of husband's underemployment on wife's labor supply.

\footnotetext{
${ }^{3}$ Programs such as unemployment insurance in addition to well-functioning capital markets help protect households from the adverse effects of negative income shocks in developed countries.

${ }^{4}$ The two countries are vastly different in level of development and labor market conditions. Serneels (2002) report over fifty percent unemployment rate among urban young men in Ethiopia whereas in Brazil unemployment rate of urban men is less than ten percent during the period studied in Felicio and Fernandes (2005).
} 
We are also interested in analyzing the effects of changes in aggregate economic conditions on labor force participation of married women. Developing countries are plagued with severe fluctuations in macroeconomic conditions. Recessions and economic crisis that result in massive layoffs are fairly common. The response of labor force participation rates to a demand induced fall in employment consists of two components---the added worker effect and the discouraged worker effect (DWE) (Lundberg, 1985). On one hand, additional labor force participants may appear in families whose employed members have experienced job loss. On the other hand, a general worsening of employment opportunities may result in discouraged workers who drop out of the labor force or refrain from entering it in anticipation of costly job search, lower wages or poor working conditions. To our knowledge our is the first paper that analyzes both the AWE and DWE in a longitudinal study.

In Turkey, prior studies on this topic are Tansel (2002) and Baslevent and Onaran (2003). Tansel analyzes the effects of unemployment rate and GDP per capita on aggregate labor participation rates of women using Population Census results from 1980, 1985 and 1990. She finds that unemployment rate has a negative effect on participation rates at the province level and concludes that the discouraged worker effect dominates the added worker effect in response to an increase in unemployment rates. Baslevent and Onaran use the Turkish Household Labor Survey data for the years 1988 and 1994 and find that in the economic crisis year of 1994, the added worker effect is dominant.

In this paper, we find evidence for a statistically significant and economically meaningful added worker effect in Turkey for years 2000-2010. Husband's involuntary job loss increases wife's labor force participation probability by 4 to 8 percent and latent (actual) hours worked by about 7 (2) hours. Married women whose husbands are underemployed are also more likely to 
participate in the labor force. However, a worsening of overall unemployment conditions has negative effect on wives' labor supply. Controlling for initial regional GDP per capita and year dummies as well as a rich set of socio-demographic factors including husband's unemployment, an increase in regional unemployment rate has a decreasing effect on wives' labor force participation and hours worked. We interpret this as evidence for discouraged worker effect of overall unemployment conditions on participation as argued by Lundberg (1985) and Tansel (2002).

Having young children has a decreasing effect while education and having other adults in the household have increasing effects on labor force participation of married women.

The rest of the paper is organized as follows. In section 2 we present the setting for female labor force participation in Turkey. Section 3 describes the data and the methodology used. Section 4 presents our empirical results. Section 5 presents concluding remarks and policy implications.

\section{Setting: Female Labor Participation in Turkey}

In Turkey, married female (including both urban and rural) LFP rate was 23.5 percent in 2009, a significantly lower rate than the OECD country average rate of 64 percent (World Bank Report 48508-TR). Turkey also has the lowest female LFP rate among the Central Asian countries. Among the pool of Islamic countries however, Turkey's female LFP rate is not an outlier. Other developing Islamic countries such as Tunisia, Morocco, Egypt and Pakistan display similar levels. 
Interestingly, LFP rate in Turkey was much higher thirty years ago. In 1980, LFP rate of working age women (including both urban and rural) was about 48 percent, a rate comparable to back then LFP rates in countries like Austria, Netherlands, Switzerland and Australia. Since mid1950s, rapid migration from rural areas to urban centers, has been continually transforming the women who were employed in the farming sector as unpaid family workers into city dwellers who are recorded as housewives in surveys. Indeed, these women who had little to no education and experience in anything outside of farming had a hard time joining the formal labor market of the urban centers (Baslevent and Onaran, 2004). The share of population that lived in urban areas was 29 percent in 1955, 44 percent in 1980, 59 percent in 1990 and 65 percent in 2000.

During the 1988-2000 period, labor force participation rates for urban women (both married and single) remains pretty stagnant around 15 percent during the 1988-2000 period while that of rural women appears to decline from 50 to 40 percent (Ozer and Bicerli, 2003). As mentioned above more and more women are working in urban areas where the labor force participation rates remain low. The decrease in labor force participation rates in rural areas might be result from the aging population in these areas as are more likely to migrate while the older people stay behind.

However, since massive migration from rural to urban areas in Turkey did not result in lower labor force participation rates for men with comparable education and experience levels, we would like to point out the women's traditional roles as childcare providers as a potential culprit in explaining decreased labor force participation rates for women. While it was possible to combine this role with working on the family farm where a woman could take her children to work or ask for help with childcare from extended family members, it was not feasible to work at a factory at minimum wage and raise children at the same time in a nuclear family household. 
While our research question centers on urban married women's labor force participation response to husband's job loss (idiosyncratic shock to the household) and a worsening of aggregate conditions (aggregate shock to households), we consider all possible determinants of female labor force participation in Turkey. According to Turkish Statistical Institute (TURKSTAT) statistics, the labor force participation of urban married women is stagnant around 13 percent during 1988-1999. In our data we observe a steady increase in labor force participation of married women during 2000-2010 period from 14 to 25 percent. The period of our study is also marked with an average GDP growth of 3.8\%. As we identify the determinants of female labor force participation, we also develop policy implications on how to improve female labor force participation in Turkey.

\section{Data and the Methodology}

We use nationally representative, yearly cross-sectional Turkish Household Labor Force Survey (HLFS) data for the 2000-2010 period, made available by TURKSTAT. There are some differences in the survey questions between the 2000-2003 and 2004-2010 periods. Most notable is that in the 2004-2010 data Turkey is divided into 26 regions. As a result, we are able to include Gross Domestic Product (GDP) per capita of the region (in million (2001) TL) and regional unemployment rate for this latter period to measure the effects of aggregate conditions in the economy on female labor force participation. ${ }^{5}$

\footnotetext{
${ }^{5}$ The most recent year that region specific GDP per capita is available is 2001 while the regional unemployment rate is available yearly for the period of study. We should note that the number of observations is also higher in the 2004-2010 period than in the 2000-2003 period.
} 
In order to examine wives' labor participation decision, we select urban households in which both husband and wife are at the ages of 20 through 54 and husband is in the labor force. We exclude households in which husband or wife is employed in agriculture sector or enrolled in education.

The labor force participation decision of wife will be analyzed using a probit model. More specifically;

$$
P_{i t}=\beta_{0}+\beta_{1} X_{i t}+\beta_{2} S_{i t}+\beta_{3} R_{i t}+\beta_{4} G_{j}+\beta_{5} M_{j t}+m_{t}+\varepsilon_{i t}
$$

Where $P_{i t}=1$ if wife of the $\mathrm{i}^{\text {th }}$ couple participates in the labor force in year t, 0 otherwise. $S_{i t}$ is husband's unemployment status and equals to 1 if husband has been fired or laid off and it is equal to 0 if husband is employed. Most empirical studies use an overall unemployment indicator for the husband. We think that this may be a problem since a choice based unemployment status such as husband's quitting his job is likely to be endogenous to the labor force participation decision of the wife. An involuntary job loss that results from a layoff or a fire is less likely to be prone to such a problem. Even this may be criticized for possible endogeneity because husband's effort level and attitude may have played a role in his being fired or laid off. One could argue that his effort level and attitude at the workplace might be endogenous to his wife's labor supply.

Husband's underemployment status is represented by $R_{i t}$ which is a dummy variable equal to 1 if the husband in the household is underemployed, 0 otherwise. We would like to control for this variable because like unemployment, it constitutes a constraint on the labor supply response of the husband. ${ }^{6}$ The vector $X$ includes demographic characteristics such as age of wife (husband), dummy variables for education levels completed for wife (husband), variables for the number of children in the household aged 0-4, 5-11 and 12-14, and the number of adults

\footnotetext{
${ }^{6}$ According to the Turkish Statistical Institute an individual is considered to be underemployed, if he is working less than 40 hours a week and would like to work more hours or he would like to change his job due to insufficient pay.
} 
(other than wife or husband) in the household that do not work. In Turkey, extended family members may live in the household and help take care of the children. This might be a factor that influences the wife's labor force participation.

GDP per capita and unemployment rates are the frequently used variables to measure the level of economic development and overall economic conditions respectively. In our econometric model, $G_{j}$ is the GDP per capita in region $\mathrm{j}$ in year $2001 ; M_{j}$ is the unemployment rate in region $\mathrm{j}$, year $\mathrm{t}$. The variable $m$ represents year dummies.

In order to analyze the labor supply response of wives fully, we also estimate a tobit model where we analyze the effects of the relevant explanatory variables defined above on the total hours of work of the wife. Total hours of work of wife is the number of hours that wife works in the reference week. In the tobit model, the data is censored for the observations in which wives work for 0 hours.

We estimate our probit and tobit models in two formats: 1) We estimate each for a single year for all years in the 2000-2010 period where we focus on the effects of household level shocks (husband's unemployment and underemployment); and 2) We pool our data and form a cross-sectional panel and estimate probit and tobit models for the pooled data. The pooled data allows us to control for aggregate conditions in the economy. Using year dummies, regional GDP per capita and regional unemployment rate we estimate the impact of recessions or economic downturns on labor force participation decisions and total labor hours of married women. According to National Bureau of Economic Research (NBER), a country is considered to be in recession if it experiences negative GDP growth rate for two consecutive quarters. According to this definition, Turkey experiences recession in the years 2001 and $2009^{7}$.

\footnotetext{
${ }^{7}$ GDP growth rates are calculated based on Real GDP and the data is taken from Turkish Central Bank database.
} 
We control for a rich set of socio-demographic factors in our estimations. Our unemployment variable is involuntary job loss of the husband. However since the study is crosssectional, one might argue that there might be unobserved heterogeneity between couples (between wives/husbands), that might influence their labor market outcome---both a husband's unemployment and his wife's labor force participation. A cross-sectional study may not adequately control for this unobserved heterogeneity and may lead to biased results. In each year's survey, there are retrospective questions on a couple's labor market outcome for the previous year. Hence we make use of these questions in order to create two year panels for each survey year that includes information on labor force participation and employment/unemployment status of each husband and his wife. We then estimate how the probability of a change in husband's employment status from employed to (involuntarily) unemployed affects his wife's labor force participation by regressing change in wife's labor force participation status on change in husband's employment status from employed to unemployed in a OLS regression framework. These results are presented in the Robustness Checks section.

\section{Results}

\subsection{Descriptive Statistics}

Figure 1 presents the labor force participation and unemployment statistics of wives during the 2000-2010 period. We only include urban wives whose husbands are in the labor force in this figure. Here labor force participation of wife, unemployment wife is calculated in the following manner:

$$
\left.L F P W=\frac{\text { number of employed } w+n u m b e r \text { of unemployed } w}{\text { number of } w} * 100 \quad \text { (equation } 2\right)
$$


Where w denotes wife. Note that the numerator in the above equation is the number of wives in labor force.

Unemploymentw $=\frac{\text { number of } \text { unemployed } w}{\text { number of } w \text { in labor force }} * 100$

This figure is presented to paint a general picture of labor market conditions for urban married women in Turkey. Hence, we use the general definition of unemployed in these figures; i.e. a person is unemployed if she is not working and looking for employment.

In Figure 1, labor force participation of married women appears to have an increasing trend in the 2000-2010 period. The 2001 and 2009 recessions are marked by sharp increases in the unemployment rate of married women.

Table 1 presents the summary statistics for variables used in this study. Note that percentage of husbands unemployed indicates the percentage of husbands who lost their job involuntarily (either fired or laid off) in our sample (the rest of the sample is composed of employed husbands). We define unemployment of husband as a job loss variable (an exogenous unemployment shock) since if unemployment of husband is voluntary (i.e. husband chose to quit his job) then this might be endogenous to wife's labor supply response.

We observe that percentage of unemployed husbands (fired or laid off) increases in both of the recession years (2001 and 2009). After 2002, there is a decreasing trend in this statistic. Both labor force participation and labor hours of wives have an increasing trend during the period of study. Labor force participation rate of married urban women increases from 14 percent in 2000 to 25 percent in 2010. Interestingly, we also observe an increase in the percentage of high-school and college educated married women during the period of study. 


\subsection{Is there an added worker effect? Single year probit and tobit estimations}

We first present probit results where the dependent variable is the labor force participation of wife. Probit results on coefficient estimates for individual years are presented in Table 2a. The corresponding marginal effects are presented in Table $2 b$.

From probit regression results, we see that involuntary unemployment status of the husband has a positive and statistically significant effect on the labor force participation probability of the wife in each year of the 2000-2010 period. A change in husband's employment status from employed to unemployed (fired or laid off) increases wife's probability of labor force

participation about 4 to 8 percent during this period. Underemployment status of the husband also has a positive and significant effect on wife's labor force participation in each year except 2002.

For years 2004-2010, we are able to control for the economic development of the region that the household resides. We find that labor force participation decision of the wife is positively and significantly associated with the 2001 GDP per capita of the region that household resides in each year except for 2010 where is negative and significant. This positive effect may be the result of increased labor market opportunities for women in more developed regions. However, there might also be unobserved heterogeneity between households residing in more and less developed areas contributing to this result.

The results on demographic variables are consistent with expectations. Educated wives are more likely to participate in the labor force. The education effect is strongest for the university graduates. University educated wives have an increased labor force participation probability of more than forty percent over only high school educated wives. In contrast, if the 
husband is educated, the wife is less likely to participate in the labor force. A husband with a college degree is likely to have a well-paying job. This might have a negative effect on married women's labor supply response (similar to husband's job loss) for two reasons: 1) income effect and 2) substitution effect (substituting wife's time for husband's in home production).

The results indicate that number of children is negatively and significantly related with the labor force participation decision of the wife. This effect is strongest for the number of children aged 0-4. Having one more child in this bracket decreases the probability of labor force participation of wives from 6 percent in 2000 to 12 percent in 2010. This is consistent with our expectations that married women with small children are less likely to participate in the labor force due to their responsibilities as caregivers at home. ${ }^{8}$

Age of wife (husband) has a positive and significant effect while age squared has a negative and significant effect on the labor force participation decision of the wife indicating the expected life cycle trend in labor supply. Finally, the number of other adults in household has a positive and significant effect on wife's labor participation. This result implies that, as the number of people who can take care of children in the household increases, the wife will tend to participate in labor force more. Interestingly, literature presents mixed results on the effect of household structure on female labor participation. Butler and Horowitz (2000) find that extended and nuclear household members do not significantly differ in participation propensities using data from Suriname whereas Maurer-Fazio et al. (2011) find that presence of an extended family member increases the likelihood of labor force participation of Chinese women. The effect of extended family on labor force participation of women is likely to be a factor of cultural norms. In Turkey, extended family members such as grandmothers and aunts have traditionally assumed

\footnotetext{
${ }^{8}$ Lokshin and Fong (2006) find that labor force participation decision of mothers is very sensitive to price of childcare.
} 
the role of childcare provider when parents need to work. Hence our results are consistent with our expectations for Turkey.

We next estimate a tobit model where we analyze the effects of the relevant explanatory variables on the total hours worked. In the tobit model, the data is censored from below since the latent dependent variable (total hours worked) takes negative values as well as positive values but only non-negative values are observed and negative values are scaled up to zero.

Similar to our probit regressions we first present single year tobit regressions in Table 3 where the effects of explanatory variables on the latent variable are shown. In single year tobit regressions, the unemployment status of the husband has a positive and significant effect on wife's labor hours in each and every year except for 2010 where it is insignificant. This is a striking result. Labor hours are a result of demand and supply conditions. It is interesting to find that wives whose husbands become involuntarily unemployed are not only willing to work as measured by their labor force participation but also are able to increase their hours worked. We should also note that this is in contrast to Maloney (1986) who does not find any significant effect of husband's unemployment status on wife's labor force participation and hours worked using data from USA. However, the magnitude of the effect varies greatly across years. A change in husband's unemployment status from employment to unemployment increases actual hours worked from one to three hours depending on the year.

When we consider the effect of husband's underemployment status on wife's labor hours we notice an even larger variance across years. Husband's underemployment status is significant in some years and insignificant in others in the tobit regressions. This is in contrast with the labor force participation regressions (probits) where the underemployment variable was positive and significant in all but one year. 
Number of children has a negative effect and education has a positive effect on wife's labor hours similar to results on participation. Number of other adults in the household seems to have a positive effect on labor hours though it is not significant in 2006 and 2010. Wife's education appears to be a very important determinant of labor hour supplied. A wife with a college degree works approximately 20 actual hours more than a wife with only a high school degree.

\subsection{Is there a discouraged worker effect? Pooled Sample Probit and Tobit estimations.}

In the single probit regressions, we see that AWE is statistically significant and economically meaningful in Turkey. We next turn our attention to the analysis of the effects of macroeconomic conditions on the labor force participation of married women. According to Lundeberg (1985) the response of labor force participation rates to a demand induced fall in employment consists of two components---the added worker effect due to household specific unemployment shocks and the discouraged worker effect due to an overall worsening of unemployment conditions. In order to determine the respective effects of these two factors on wife's labor force participation decision we pool our data and form a panel of cross-sectional yearly data for 2000-2010. This is an interesting period in Turkey because it includes severe fluctuations in overall GDP growth rate and unemployment rate.

Table 4 presents pooled sample probit results with year dummies. The first column presents the effects of husband's involuntary unemployment on wife's labor force participation in a regression including all the socio-demographic variables used in Table $2 \mathrm{a}$ except for the husband's underemployment status variable. Column 2 includes husband's underemployment 
status in addition to explanatory variables used in column 1. Column 3 includes regional unemployment rate and regional GDP per capita in 2001 variables in addition to variables used in column 2. Since household's residential region information is only available starting from 2004, the regression in column 3 is for years 2004-2010 and the 2004 year dummy is the excluded dummy variable. In all three columns husband's involuntary job loss has a positive and significant effect on wife's labor force participation decision. A change in husband's unemployment status from employment to involuntary unemployment increases the probability of wife's labor force participation by 6 percentage points in the first two columns. Similarly, a wife whose husband is underemployed is 5 percentage points more likely to participate in the labor force. The effects of other socio-demographic variables are comparable across three specifications and also consistent with the yearly cross-sectional regressions of Table $2 \mathrm{a}$.

When we include our measures for aggregate conditions, we observe that the marginal effect of husband's unemployment slightly decreases to 5 percentage points while the marginal effect of husband's underemployment increases to 8 percentage points. When we consider the effect of regional unemployment rate on wife's labor force participation decision, we observe that as the regional unemployment rate increases, probability that a wife will participate in the labor force decreases. A one percentage point increase in the unemployment rate decreases probability of participation by 2.75 percentage points. Hence a worsening of overall employment conditions appears to have a discouraging effect on wife's labor force participation. ${ }^{9}$

${ }^{9}$ We also considered the effect of national unemployment rate on wife's labor force participation in a regression with a time trend variable instead of year dummies. Since national unemployment rate is available for each year of the period of our study, we are able estimate 
Similar to single year probit regressions, we find that labor force participation decision of the wife is positively and significantly associated with the regional GDP per capita. As mentioned before, this variable is a proxy for the increased labor market opportunities for women in more developed regions and hence its positive effect on participation is consistent with expectations.

Table 5 presents our pooled tobit estimations with year dummies. Similar to Table 4, The first column controls for husband's unemployment status and the second column controls for both husband's unemployment and underemployment status, the third column controls for our measures of aggregate conditions in addition to husband's unemployment and underemployment. The socio-demographic variables are same as in Table 4. We find that both husband's unemployment and underemployment status have positive and significant effects when observations for the ten years are pooled together. A change in husband's employment status from employment to unemployment increases wife's latent hours worked by 7 hours and actual hours worked by 1-2 hours. Regional unemployment rate has a negative and significant effect on wife's work hours while GDP per capita has a positive and significant effect consistent with expectations.

this regression for the whole 2000-2010 period. We again found a negative an significant effect of unemployment rate. These results though not presented for brevity are available upon request. 


\subsection{Robustness Checks}

\section{Panel data analysis}

In each year's cross-sectional household survey there are questions on the labor market outcomes of household members in the year before. Hence we know the labor force participation status, employment/unemployment status of each household member in each cross-sectional sample for two consequent years. In this section we restrict the sample to husbands who were employed in the previous year. We then analyze how involuntary unemployment status of the husband in the current year changes wife's labor force participation status across the two years.

Hence, in this regression the dependent variable is wife's change in labor force participation, which is equal to 1 if a wife who was not in the labor force in the previous year joins the labor force in the current year, -1 if a wife who was in the labor force in the previous year, is no longer in the labor force in the current year and 0 if there is no change in her labor force participation status. The explanatory variable is husband's unemployment status which is equal to 1 if husband has lost his job involuntarily in the current year and 0 otherwise. For example among the 39483 employed husbands in year 2004, 585 of them have lost their jobs involuntarily (fired or laid off) in year 2005. Table 6a presents the summary statistics for the six two year panels. According to this table, approximately 1 to 2 percent of husbands who were employed in the previous year lose their jobs involuntarily in the current year. Table $6 \mathrm{~b}$ presents the regression results where change in wife's labor force participation status is regressed on husband's unemployment status. In each panel, we find that a change in husband's employment status from employed to involuntarily unemployed significantly increases his wife's labor force participation. Since the percentage of husbands who lose their jobs involuntarily is rather small, we also replicated this experiment for husbands who have experienced a job loss for any reason. 
About 4 percent of husbands who were employed in the previous year become unemployed in the current year for a number of reasons. When we regress change in wife's labor force participation status on husband's unemployment variable which is equal to 1 if husband has lost his job (voluntarily or involuntarily) in current year and zero otherwise, we again find a positive and significant effect of husband's job loss on his wife's labor force participation. These results though not presented for brevity are available upon request.

Wife's education level and the added worker effect

From our results, education appears to be a very important factor of wife's labor force participation decision. Education may also affect her market opportunities to deal with unemployment risk. In developing countries education levels tend to be lower than developed countries where studies find little or no evidence for the added worker effect. Hence it is worthwhile to examine the magnitude and significance of the added worker effect across different education levels. In Table 7, we present pooled sample probit and tobit estimations for subsamples of women with different education levels for the $2000-2010$ period. While the added worker effect is present for women with less than a college education, for college graduates we no longer find that husband's job loss has a significant effect on wife's labor force participation decision. This is a potentially interesting result and can account for some of the differences between empirical studies from developed and developing countries. For those with less than a college education the magnitude of the added worker effect is largest for high school graduates. For this group, husband's job loss increases the probability of wife's labor force participation by 7 percentage points.

We also estimated pooled sample probit and tobit regressions including our measures for aggregate conditions for subsamples of women with different education levels for the 2004-2010 
period. In these estimations regional unemployment rate appears to have a negative and significant effect on married women's labor force participation in all sub-samples except for the sample of women with college degrees. For this group, unemployment rate appears to be insignificant. Hence women with a college degree are less likely to become discouraged workers.

\section{Conclusion}

This paper examines the significance of married women's labor supply response to husbands' job loss (added worker effect, AWE) and a worsening of overall employment conditions (discouraged worker effect, DWE) in Turkey for the 2000-2010 period. We find a statistically significant and economically meaningful AWE for Turkey as married women increase both their labor force participation and hours worked in response to husbands' involuntary job loss. This effect seems strongest for high school graduates. We also find that a worsening of overall economic conditions measured with yearly regional unemployment rates has a negative effect on wives' labor force participation and hours worked. To our knowledge our is the first paper that analyzes both the AWE and DWE in a longitudinal study.

We find that the underemployment status of husband has a positive and significant effect on the labor force participation decision of wives while its effect on hours worked is generally small and insignificant in some specifications. Ours is the first study that examines the effect of husband's underemployment status on wife's labor supply response using data from a developing country.

In conclusion, labor supply of married women responds positively to husbands' job loss and underemployment and negatively to a decrease in overall unemployment opportunities. However, their traditional roles as caregivers for children and low education levels stand in the 
way of their greater participation in the labor market. It is interesting to note that the number of other adults in the household has an increasing effect on LFP of women. This might be due the tradition role of extended family members as providers of childcare. Further research is needed on existing and potential childcare arrangements that will help women to have a greater participation in the labor market. 


\section{References}

Ashenfelter, Orley. 1980. "Unemployment as Disequilibrium in a Model of Aggregate Labor Supply,” Econometrica 48(3): 547-564.

Başlevent, Cem and Özlem Onaran. 2003. "Are Married Women in Turkey More Likely to Become Added or Discouraged Workers," Labor 17(3): 439-458.

Baslevent, Cem and Ozlem Onaran. 2004. "The Effect of Export Oriented Growth on Female Labor Market Outcomes in Turkey," World Development 32(8): 1375-1393.

Besley, Timothy. 1995. "Non-market Institutions for Credit and Risk Sharing in Low Income Countries," Journal of Economic Perspectives, 9(3): 115-127.

Butler J.S. and Andrew Horowitz. 2000. "Labor Supply and Wages among Nuclear and Extended Households: Surinamese Experiment" Journal of Development Studies 36, 5:1-29.

Cullen, Julie Berry and Jonathan Gruber. 2000. "Does Unemployment Insurance Crowd Out Spousal Labor Supply,” Journal of Labor Economics 18(3): 546-572.

Fernandes, Reynaldo and Fabiana De Felicio. 2005. "The Entry of the Wife into the Labor Force in Response to the Household's Unemployment: A Study of the Added Worker Effect in Brazilian Metropolitan Areas," Economic Development and Cultural Change 54(3): 887-911.

Heckman, J and T. MaCurdy. 1980. "A Life cycle Model of Female Labor Supply," Review of Economic Studies 47: 47-74

Klasen Stephan 2002. "Low Schooling for Girls, Slower Growth for All? Cross Country Evidence on the Effect of Gender Inequality in Education on Economic Development. World Bank Economic Review 16, 3: 345-373.

Kohara, Miki. 2010. “The Response of Japanese Wives' Labor Supply to Husbands' Job Loss”, Journal of Population Economics, 23: 1133-1149. 
Lokshin Michael and Monica Fong 2006. “Women's Labor Force Participation and Childcare in Romania", Journal of Development Studies, 42(1) :90-109.

Lundberg, Shelly.1985. “The Added Worker Effect”, Journal of Labor Economics 3(1):11-37

Maloney, Tim. 1986. "Employment Constraints and the Labor Supply of Married Women A Reexamination of the Added Worker Effect," The Journal of Human Resources 12(1): 51-60.

Maloney, Tim. 1991. "Unobserved Variables and the Elusive Added Worker Effect," Economica, New Series 58(230): 173-187.

Maurer-Fazio Margaret; Connelly Rachel; Lan Chen; Ixin Tang (2011). "Childcare, Eldercare and Labor Force Participation of Married Women in Urban China, 1982-2000" Journal of Human Resources, 46, 2:261-294.

Ozer, Mustafa and Kemal Bicerli. (2003). “Turkiye'de Kadin Isgucunun Panel Veri Analizi”, Sosyal Bilimler Dergisi.

Prieto-Rodriguez, Juan and César Rodriguez-Guitiérrez.2003. "Participation of married women in the European labor markets and the 'added worker effect'", Journal of Socio-Economics 32: 429-446Serneels, Pieter. 2002. "The Added Worker Effect and Intrahousehold Aspects of Unemployment." The Center for the Study of African Economies Working Paper Series, No.173. Spletzer, James R. 1997. "Reexamining the Added Worker Effect," Economic Inquiry 35: 417427.

Stephens, Melvin. 2002. "Worker Displacement and the Added Worker Effect," Journal of Labor Econoics 20(3): 504-537.

Tansel, Aysit. 2002. "Economic Development and Female Labor Force Participation in Turkey: Time Series Evidence and Cross-Province Estimates", Employment of Women. Ankara: Turkish Statistical Institute, No:2594, pp: 111-151. 
World Bank Report by Mason Andrew and Elizabeth King (2001). "Engendering Development through Gender Equality in Rights, Resources and Voice.

World Bank Report 48508-TR (2009). "Female Labor Force Participation in Turkey: Trends

Determinants and Policy Framework". Human Development Sector Unit Europe and Central Asia Region. 


\section{Figure 1}

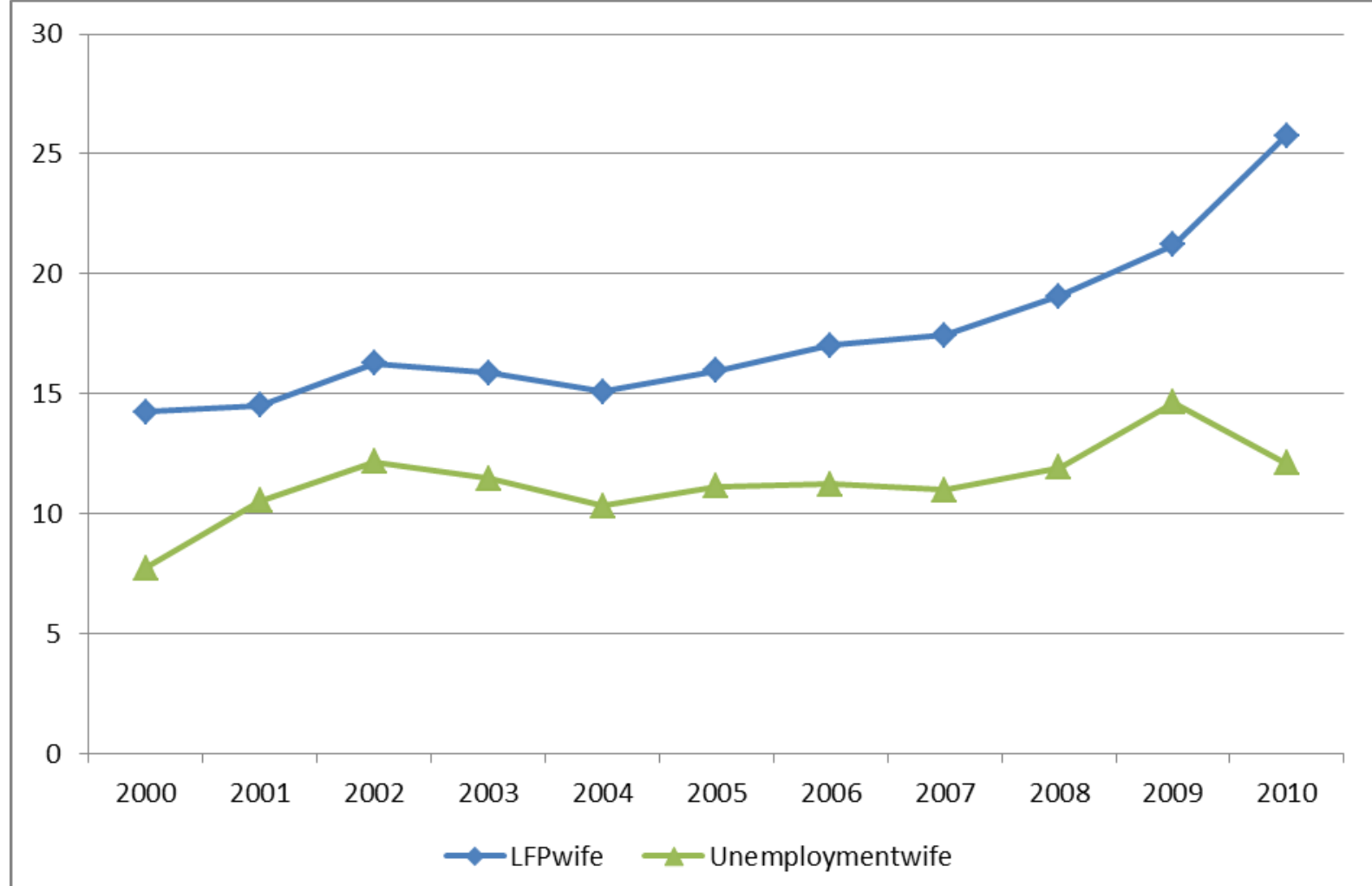

Figure1. Employment and labor force participation (\%) status of married urban women aged between 20-54 years old and whose husbands are in labor force. 
Table 1: Summary Statistics of the Variables for the period 2000-2010 ${ }^{10}$

\begin{tabular}{|c|c|c|c|c|c|c|c|c|c|c|c|}
\hline Variables & 2000 & 2001 & 2002 & 2003 & 2004 & 2005 & 2006 & 2007 & 2008 & 2009 & 2010 \\
\hline $\begin{array}{l}\text { Share of Husbands } \\
\text { Unemployed }\end{array}$ & $\begin{array}{l}0.01 \\
(0.10)\end{array}$ & $\begin{array}{l}0.02 \\
(0.15)\end{array}$ & $\begin{array}{l}0.04 \\
(0.20)\end{array}$ & $\begin{array}{l}0.03 \\
(0.18)\end{array}$ & $\begin{array}{l}\mathbf{0 . 0 3} \\
(0.17)\end{array}$ & $\begin{array}{l}0.03 \\
(0.17) \\
\end{array}$ & $\begin{array}{l}0.02 \\
(0.16)\end{array}$ & $\begin{array}{l}0.02 \\
(0.15) \\
\end{array}$ & $\begin{array}{l}0.02 \\
(0.16)\end{array}$ & $\begin{array}{l}0.04 \\
(0.21)\end{array}$ & $\begin{array}{l}0.03 \\
(0.1\end{array}$ \\
\hline $\begin{array}{l}\text { Share of Husbands } \\
\text { Underemployed }\end{array}$ & $\begin{array}{l}0.08 \\
(0.28) \\
\end{array}$ & $\begin{array}{l}0.07 \\
(0.26) \\
\end{array}$ & $\begin{array}{l}0.06 \\
(0.25) \\
\end{array}$ & $\begin{array}{l}0.05 \\
(0.23) \\
\end{array}$ & $\begin{array}{l}0.03 \\
(0.19) \\
\end{array}$ & $\begin{array}{l}0.01 \\
(0.10) \\
\end{array}$ & $\begin{array}{l}0.01 \\
(0.11) \\
\end{array}$ & $\begin{array}{l}0.01 \\
(0.10) \\
\end{array}$ & $\begin{array}{l}0.01 \\
(0.10) \\
\end{array}$ & $\begin{array}{l}0.02 \\
(0.14) \\
\end{array}$ & $\begin{array}{l}0.01 \\
(0.1 \\
\end{array}$ \\
\hline Husband's age & $\begin{array}{l}38.26 \\
(7.63)\end{array}$ & $\begin{array}{l}38.25 \\
(7.62)\end{array}$ & $\begin{array}{l}38.31 \\
(7.67)\end{array}$ & $\begin{array}{l}38.33 \\
(7.69)\end{array}$ & $\begin{array}{l}38.43 \\
(7.58)\end{array}$ & $\begin{array}{l}38.55 \\
(7.66)\end{array}$ & $\begin{array}{l}38.60 \\
(7.72)\end{array}$ & $\begin{array}{l}38.66 \\
(7.68)\end{array}$ & $\begin{array}{l}38.74 \\
(7.67)\end{array}$ & $\begin{array}{l}38.85 \\
(7.65)\end{array}$ & $\begin{array}{l}39.32 \\
(7.69)\end{array}$ \\
\hline Wife's age & $\begin{array}{l}34.31 \\
(7.75)\end{array}$ & $\begin{array}{l}34.34 \\
(7.75)\end{array}$ & $\begin{array}{l}34.43 \\
(7.80)\end{array}$ & $\begin{array}{l}34.48 \\
(7.83)\end{array}$ & $\begin{array}{l}34.69 \\
(7.82)\end{array}$ & $\begin{array}{l}\mathbf{3 4 . 8 5} \\
(\mathbf{7 . 8 8})\end{array}$ & $\begin{array}{l}34.89 \\
(7.97)\end{array}$ & $\begin{array}{l}35.00 \\
(7.92)\end{array}$ & $\begin{array}{l}35.15 \\
(7.87)\end{array}$ & $\begin{array}{l}35.21 \\
(7.87)\end{array}$ & $\begin{array}{l}35.73 \\
(7.91)\end{array}$ \\
\hline Children (0-4) & $\begin{array}{l}0.42 \\
(0.63)\end{array}$ & $\begin{array}{l}0.43 \\
(0.62)\end{array}$ & $\begin{array}{l}0.43 \\
(0.62)\end{array}$ & $\begin{array}{l}0.42 \\
(0.62)\end{array}$ & $\begin{array}{l}0.43 \\
(0.63)\end{array}$ & $\begin{array}{l}0.43 \\
(0.62)\end{array}$ & $\begin{array}{l}0.43 \\
(0.63)\end{array}$ & $\begin{array}{c}0.43 \\
(0.62)\end{array}$ & $\begin{array}{c}0.43 \\
(0.63)\end{array}$ & $\begin{array}{l}0.44 \\
(0.64)\end{array}$ & $\begin{array}{c}0.43 \\
(0.62)\end{array}$ \\
\hline Children (5-11) & $\begin{array}{l}0.75 \\
(0.87) \\
\end{array}$ & $\begin{array}{l}0.73 \\
(0.85) \\
\end{array}$ & $\begin{array}{l}0.72 \\
(0.84)\end{array}$ & $\begin{array}{l}0.71 \\
(0.83) \\
\end{array}$ & $\begin{array}{l}0.72 \\
(0.85)\end{array}$ & $\begin{array}{l}0.74 \\
(0.86)\end{array}$ & $\begin{array}{l}0.72 \\
(0.85)\end{array}$ & $\begin{array}{c}0.70 \\
(0.83)\end{array}$ & $\begin{array}{l}0.68 \\
(0.82)\end{array}$ & $\begin{array}{l}0.67 \\
(0.81)\end{array}$ & $\begin{array}{c}0.66 \\
(0.80)\end{array}$ \\
\hline Children (12-14) & $\begin{array}{l}0.31 \\
(0.54)\end{array}$ & $\begin{array}{l}0.30 \\
(0.54)\end{array}$ & $\begin{array}{l}0.29 \\
(0.53)\end{array}$ & $\begin{array}{l}0.29 \\
(0.53)\end{array}$ & $\begin{array}{l}0.29 \\
(0.53)\end{array}$ & $\begin{array}{l}0.29 \\
(0.53)\end{array}$ & $\begin{array}{l}0.27 \\
(0.51)\end{array}$ & $\begin{array}{l}0.27 \\
(0.51)\end{array}$ & $\begin{array}{l}0.27 \\
(0.51)\end{array}$ & $\begin{array}{l}0.27 \\
(0.51)\end{array}$ & $\begin{array}{c}0.28 \\
(0.51)\end{array}$ \\
\hline Husband not grad. & $\begin{array}{l}0.01 \\
(0.12)\end{array}$ & $\begin{array}{l}0.01 \\
(0.12)\end{array}$ & $\begin{array}{l}0.01 \\
(0.10)\end{array}$ & $\begin{array}{l}0.01 \\
(0.10)\end{array}$ & $\begin{array}{l}0.01 \\
(0.12)\end{array}$ & $\begin{array}{l}0.02 \\
(0.14)\end{array}$ & $\begin{array}{l}0.01 \\
(0.13)\end{array}$ & $\begin{array}{l}0.01 \\
(0.13)\end{array}$ & $\begin{array}{l}0.01 \\
(0.12)\end{array}$ & $\begin{array}{l}0.01 \\
(0.13)\end{array}$ & $\begin{array}{c}0.02 \\
(0.16)\end{array}$ \\
\hline $\begin{array}{l}\text { Husband primary } \\
\text { grad. }\end{array}$ & $\begin{array}{l}0.49 \\
(0.49) \\
\end{array}$ & $\begin{array}{l}0.49 \\
(0.49) \\
\end{array}$ & $\begin{array}{l}0.47 \\
(0.49) \\
\end{array}$ & $\begin{array}{l}0.45 \\
(0.49) \\
\end{array}$ & $\begin{array}{l}0.45 \\
(0.49) \\
\end{array}$ & $\begin{array}{l}0.45 \\
(0.49) \\
\end{array}$ & $\begin{array}{l}0.44 \\
(0.49) \\
\end{array}$ & $\begin{array}{l}0.43 \\
(0.49) \\
\end{array}$ & $\begin{array}{l}0.43 \\
(0.49) \\
\end{array}$ & $\begin{array}{l}0.42 \\
(0.49) \\
\end{array}$ & $\begin{array}{c}0.42 \\
(0.49) \\
\end{array}$ \\
\hline $\begin{array}{l}\text { Husband middle } \\
\text { grad. }\end{array}$ & $\begin{array}{l}0.12 \\
(0.33)\end{array}$ & $\begin{array}{l}0.13 \\
(0.33)\end{array}$ & $\begin{array}{l}0.13 \\
(0.34)\end{array}$ & $\begin{array}{l}0.13 \\
(0.34)\end{array}$ & $\begin{array}{l}0.13 \\
(0.34)\end{array}$ & $\begin{array}{l}0.13 \\
(0.34)\end{array}$ & $\begin{array}{l}0.13 \\
(0.34)\end{array}$ & $\begin{array}{l}0.13 \\
(0.34)\end{array}$ & $\begin{array}{l}0.13 \\
(0.34)\end{array}$ & $\begin{array}{l}0.13 \\
(0.34)\end{array}$ & $\begin{array}{c}0.13 \\
(0.34) \\
\end{array}$ \\
\hline Husband high grad. & $\begin{array}{l}0.21 \\
(0.41) \\
\end{array}$ & $\begin{array}{l}0.21 \\
(0.41) \\
\end{array}$ & $\begin{array}{l}0.22 \\
(0.41) \\
\end{array}$ & $\begin{array}{l}0.23 \\
(0.42) \\
\end{array}$ & $\begin{array}{l}0.24 \\
(0.42) \\
\end{array}$ & $\begin{array}{l}0.23 \\
(0.42) \\
\end{array}$ & $\begin{array}{l}0.24 \\
(0.42) \\
\end{array}$ & $\begin{array}{l}0.24 \\
(0.43) \\
\end{array}$ & $\begin{array}{l}0.24 \\
(0.42) \\
\end{array}$ & $\begin{array}{l}0.24 \\
(0.42) \\
\end{array}$ & $\begin{array}{r}0.23 \\
(0.4 \\
\end{array}$ \\
\hline $\begin{array}{l}\text { Husband college } \\
\text { grad. }\end{array}$ & $\begin{array}{l}0.12 \\
(0.33) \\
\end{array}$ & $\begin{array}{l}0.13 \\
(0.33) \\
\end{array}$ & $\begin{array}{l}0.14 \\
(0.35) \\
\end{array}$ & $\begin{array}{l}0.14 \\
(0.35) \\
\end{array}$ & $\begin{array}{l}0.14 \\
(0.34) \\
\end{array}$ & $\begin{array}{l}0.14 \\
(0.35) \\
\end{array}$ & $\begin{array}{l}0.14 \\
(0.35) \\
\end{array}$ & $\begin{array}{l}0.15 \\
(0.36) \\
\end{array}$ & $\begin{array}{l}0.15 \\
(0.36) \\
\end{array}$ & $\begin{array}{l}0.16 \\
(0.37) \\
\end{array}$ & $\begin{array}{c}0.17 \\
(0.37) \\
\end{array}$ \\
\hline Wife not grad. & $\begin{array}{l}0.03 \\
(0.17) \\
\end{array}$ & $\begin{array}{l}0.02 \\
(0.16) \\
\end{array}$ & $\begin{array}{l}0.02 \\
(0.16) \\
\end{array}$ & $\begin{array}{l}0.02 \\
(0.16) \\
\end{array}$ & $\begin{array}{l}\mathbf{0 . 0 3} \\
(0.17) \\
\end{array}$ & $\begin{array}{l}0.04 \\
(0.19) \\
\end{array}$ & $\begin{array}{l}0.04 \\
(0.20) \\
\end{array}$ & $\begin{array}{l}0.04 \\
(0.20)\end{array}$ & $\begin{array}{l}0.04 \\
(0.21) \\
\end{array}$ & $\begin{array}{l}0.05 \\
(0.22) \\
\end{array}$ & $\begin{array}{c}0.12 \\
(0.33) \\
\end{array}$ \\
\hline Wife primary grad. & $\begin{array}{l}0.57 \\
(0.49) \\
\end{array}$ & $\begin{array}{l}0.57 \\
(0.49)\end{array}$ & $\begin{array}{l}0.56 \\
(0.49)\end{array}$ & $\begin{array}{l}0.55 \\
(0.49) \\
\end{array}$ & $\begin{array}{l}0.55 \\
(0.49) \\
\end{array}$ & $\begin{array}{l}0.54 \\
(0.49)\end{array}$ & $\begin{array}{l}0.53 \\
(0.49) \\
\end{array}$ & $\begin{array}{l}0.53 \\
(0.49) \\
\end{array}$ & $\begin{array}{l}0.52 \\
(0.49) \\
\end{array}$ & $\begin{array}{l}0.50 \\
(0.50)\end{array}$ & $\begin{array}{l}0.50 \\
(0.4 \\
\end{array}$ \\
\hline Wife middle grad. & $\begin{array}{l}0.07 \\
(0.26) \\
\end{array}$ & $\begin{array}{l}0.07 \\
(0.26) \\
\end{array}$ & $\begin{array}{l}0.08 \\
(0.27) \\
\end{array}$ & $\begin{array}{l}0.08 \\
(0.27) \\
\end{array}$ & $\begin{array}{l}0.08 \\
(0.27) \\
\end{array}$ & $\begin{array}{l}0.08 \\
(0.27) \\
\end{array}$ & $\begin{array}{l}0.08 \\
(0.27) \\
\end{array}$ & $\begin{array}{l}0.08 \\
(0.28) \\
\end{array}$ & $\begin{array}{l}0.08 \\
(0.28) \\
\end{array}$ & $\begin{array}{l}0.09 \\
(0.29) \\
\end{array}$ & $\begin{array}{c}0.09 \\
(0.29)\end{array}$ \\
\hline Wife high grad. & $\begin{array}{l}0.14 \\
(0.35) \\
\end{array}$ & $\begin{array}{l}0.14 \\
(0.35) \\
\end{array}$ & $\begin{array}{l}0.15 \\
(0.36) \\
\end{array}$ & $\begin{array}{l}0.16 \\
(0.37) \\
\end{array}$ & $\begin{array}{l}0.16 \\
(0.37) \\
\end{array}$ & $\begin{array}{l}0.16 \\
(0.36) \\
\end{array}$ & $\begin{array}{l}0.16 \\
(0.37) \\
\end{array}$ & $\begin{array}{l}0.17 \\
(0.37) \\
\end{array}$ & $\begin{array}{l}0.17 \\
(0.38) \\
\end{array}$ & $\begin{array}{l}0.17 \\
(0.38) \\
\end{array}$ & $\begin{array}{l}0.17 \\
(0.3 \\
\end{array}$ \\
\hline Wife college grad. & $\begin{array}{l}0.06 \\
(0.25)\end{array}$ & $\begin{array}{l}0.06 \\
(0.25)\end{array}$ & $\begin{array}{l}0.07 \\
(0.26)\end{array}$ & $\begin{array}{l}0.08 \\
(0.27)\end{array}$ & $\begin{array}{l}0.07 \\
(0.25)\end{array}$ & $\begin{array}{l}0.07 \\
(0.26)\end{array}$ & $\begin{array}{l}0.08 \\
(0.27)\end{array}$ & $\begin{array}{l}0.08 \\
(0.27)\end{array}$ & $\begin{array}{l}0.08 \\
(0.28)\end{array}$ & $\begin{array}{l}0.09 \\
(0.29)\end{array}$ & $\begin{array}{c}0.10 \\
(0.30) \\
\end{array}$ \\
\hline LFP of wife & $\begin{array}{l}0.14 \\
(0.34)\end{array}$ & $\begin{array}{l}0.14 \\
(0.35)\end{array}$ & $\begin{array}{l}0.16 \\
(0.36)\end{array}$ & $\begin{array}{l}0.15 \\
(0.36)\end{array}$ & $\begin{array}{l}0.15 \\
(0.35) \\
\end{array}$ & $\begin{array}{l}0.15 \\
(0.36)\end{array}$ & $\begin{array}{l}0.17 \\
(0.37) \\
\end{array}$ & $\begin{array}{l}0.17 \\
(0.37) \\
\end{array}$ & $\begin{array}{l}0.19 \\
(0.39) \\
\end{array}$ & $\begin{array}{l}0.21 \\
(0.40) \\
\end{array}$ & $\begin{array}{c}0.25 \\
(0.43)\end{array}$ \\
\hline $\begin{array}{l}\text { Total hours of work of } \\
\text { wife }\end{array}$ & $\begin{array}{l}5.12 \\
(14.39) \\
\end{array}$ & $\begin{array}{l}5.07 \\
(14.30) \\
\end{array}$ & $\begin{array}{l}5.71 \\
(15.32) \\
\end{array}$ & $\begin{array}{l}5.65 \\
(15.22) \\
\end{array}$ & $\begin{array}{l}5.88 \\
(15.62) \\
\end{array}$ & $\begin{array}{l}6.11 \\
(15.95) \\
\end{array}$ & $\begin{array}{l}6.51 \\
(16.46) \\
\end{array}$ & $\begin{array}{l}6.66 \\
(16.51) \\
\end{array}$ & $\begin{array}{l}7.24 \\
(17.18) \\
\end{array}$ & $\begin{array}{l}7.47 \\
(17.17) \\
\end{array}$ & $\begin{array}{l}8.16 \\
(17.59 \\
\end{array}$ \\
\hline $\begin{array}{l}\text { Other adults in the } \\
\text { household }\end{array}$ & $\begin{array}{l}0.06 \\
(0.30)\end{array}$ & $\begin{array}{l}0.06 \\
(0.30)\end{array}$ & $\begin{array}{l}0.07 \\
(0.32)\end{array}$ & $\begin{array}{l}0.06 \\
(0.30)\end{array}$ & $\begin{array}{l}0.08 \\
(0.34)\end{array}$ & $\begin{array}{l}0.08 \\
(0.34)\end{array}$ & $\begin{array}{l}0.09 \\
(0.36)\end{array}$ & $\begin{array}{l}0.08 \\
(0.35)\end{array}$ & $\begin{array}{l}0.08 \\
(0.35)\end{array}$ & $\begin{array}{l}0.09 \\
(0.40)\end{array}$ & $\begin{array}{l}0.07 \\
(0.3\end{array}$ \\
\hline GDP growth rate $(\%)$ & 6.77 & -5.70 & 6.16 & 5.27 & 9.36 & 8.40 & 6.89 & 4.67 & 0.66 & -4.83 & 9.00 \\
\hline $\begin{array}{l}\text { General Unemployment } \\
\text { Rate }(\%) \text { of Turkey }\end{array}$ & 6.50 & 8.40 & 10.30 & 10.50 & 10.80 & 10.60 & 10.20 & 10.30 & 11.00 & 14.00 & 11.90 \\
\hline $\mathbf{N}$ & 30036 & 30164 & 29535 & 29340 & 41539 & 41831 & 42064 & 41892 & 41770 & 42831 & 48060 \\
\hline
\end{tabular}

${ }^{10}$ GDP growth rate and unemployment rate are calculated annually. The data are taken from the Central Bank of Turkish Rebublic database (GDP Growth Rate) and TURKSTAT(Unemployment Rate). 
Table 2a. Probit Results. Dependent variable: Wife's labor force participation

\begin{tabular}{|c|c|c|c|c|c|c|c|c|c|c|c|}
\hline Variable & 2000 & 2001 & 2002 & 2003 & 2004 & 2005 & 2006 & 2007 & 2008 & 2009 & 2010 \\
\hline Husband unemployed & $\begin{array}{l}0.40 * * \\
(0.08)\end{array}$ & $\begin{array}{l}\mathbf{0 . 3 8} * * * \\
(\mathbf{0 . 0 6}) \\
\end{array}$ & $\begin{array}{l}\mathbf{0 . 3 1} * * * \\
(\mathbf{0 . 0 4}) \\
\end{array}$ & $\begin{array}{l}0.35 * * * \\
(0.04) \\
\end{array}$ & $\begin{array}{l}0.27 * * * \\
(0.04)\end{array}$ & $\begin{array}{l}0.21 * * * \\
(0.04)\end{array}$ & $\begin{array}{l}0.27 * * * \\
(\mathbf{0 . 0 4}) \\
\end{array}$ & $\begin{array}{l}0.22 * * * \\
(0.04) \\
\end{array}$ & $\begin{array}{l}0.21 * * * \\
(0.04)\end{array}$ & $\begin{array}{l}0.22 * * * \\
(\mathbf{0 . 0 3}) \\
\end{array}$ & $\begin{array}{l}0.12 * * * \\
(\mathbf{0 . 0 3}) \\
\end{array}$ \\
\hline Husband underemployed & $\begin{array}{l}0.14 * * * \\
(0.03)\end{array}$ & $\begin{array}{l}0.20 * * * \\
(\mathbf{0 . 0 3})\end{array}$ & $\begin{array}{l}-0.01 \\
(0.04)\end{array}$ & $\begin{array}{l}0.30 * * * \\
(0.04)\end{array}$ & $\begin{array}{l}0.21 * * * \\
(0.04)\end{array}$ & $\begin{array}{l}0.34 * * * \\
(0.07)\end{array}$ & $\begin{array}{l}0.30 * * * \\
(0.06)\end{array}$ & $\begin{array}{l}0.21 * * * \\
(0.07) \\
\end{array}$ & $\begin{array}{l}0.31 * * * \\
(0.07)\end{array}$ & $\begin{array}{l}0.34 * * * \\
(0.04)\end{array}$ & $\begin{array}{l}0.39 * * * \\
(0.04)\end{array}$ \\
\hline Husband's age & $\begin{array}{l}0.13 * * * \\
(0.02)\end{array}$ & $\begin{array}{l}0.09 * * * \\
(0.03)\end{array}$ & $\begin{array}{l}0.08 * * * \\
(0.01)\end{array}$ & $\begin{array}{l}0.07 * * * \\
(0.02)\end{array}$ & $\begin{array}{l}0.05 * * * \\
(0.01)\end{array}$ & $\begin{array}{l}0.04 * * * \\
(0.01)\end{array}$ & $\begin{array}{l}0.09 * * * \\
(0.01)\end{array}$ & $\begin{array}{l}0.05 * * * \\
(0.01)\end{array}$ & $\begin{array}{l}0.08 * * * \\
(0.01)\end{array}$ & $\begin{array}{l}0.06 * * * \\
(0.01)\end{array}$ & $\begin{array}{l}0.06 * * * \\
(0.01)\end{array}$ \\
\hline Husband's age squared (in 100) & $\begin{array}{l}-0.20 * * * \\
(\mathbf{0 . 0 3}) \\
\end{array}$ & $\begin{array}{l}-\mathbf{0 . 1 4} * * * \\
(\mathbf{0 . 0 4 )} \\
\end{array}$ & $\begin{array}{l}-0.12 * * * \\
(0.02) \\
\end{array}$ & $\begin{array}{l}-\mathbf{- 0 . 1 2 * * * *} \\
(\mathbf{0 . 0 3}) \\
\end{array}$ & $\begin{array}{l}-0.08 \text { **** } \\
(0.01)\end{array}$ & $\begin{array}{l}-0.08 * * * \\
(0.01) \\
\end{array}$ & $\begin{array}{l}-0.13 * * * \\
(0.01)\end{array}$ & $\begin{array}{l}-0.07 * * * \\
(0.01)\end{array}$ & $\begin{array}{l}-0.11 * * * * \\
(0.01)\end{array}$ & $\begin{array}{l}-0.09 * * * \\
(0.01) \\
\end{array}$ & $\begin{array}{l}-0.08 * * * * \\
(0.01)\end{array}$ \\
\hline Wife's age & $\begin{array}{l}0.07 * * * \\
(0.04) \\
\end{array}$ & $\begin{array}{l}.09 * * \\
(0.04)\end{array}$ & $\begin{array}{l}0.14 * * * \\
(0.01) \\
\end{array}$ & $\begin{array}{l}0.12 * * * * \\
(0.03)\end{array}$ & $\begin{array}{l}0.15 * * * \\
(0.01)\end{array}$ & $\begin{array}{l}\text { 0.16**** } \\
(0.01)\end{array}$ & $\begin{array}{l}0.12 * * * \\
(0.01)\end{array}$ & $\begin{array}{l}0.16 * * * \\
(0.01) \\
\end{array}$ & $\begin{array}{l}0.13 * * * \\
(0.01) \\
\end{array}$ & $\begin{array}{l}0.14 * * * \\
(0.01) \\
\end{array}$ & $\begin{array}{l}0.11 * * * \\
(0.009)\end{array}$ \\
\hline $\begin{array}{l}\text { Wife's age squared } \\
\text { (in 100) }\end{array}$ & $\begin{array}{l}-0.10 * * \\
(0.05) \\
\end{array}$ & $\begin{array}{l}-0.12 * * \\
(0.06) \\
\end{array}$ & $\begin{array}{l}-0.20 * * * * \\
(0.02) \\
\end{array}$ & $\begin{array}{l}-0.17 * * * * \\
(0.05) \\
\end{array}$ & $\begin{array}{l}-0.21 * * * * \\
(0.01)\end{array}$ & $\begin{array}{l}-0.23 * * * \\
(0.01) \\
\end{array}$ & $\begin{array}{l}-0.17 * * * \\
(0.01)\end{array}$ & $\begin{array}{l}-0.23 * * * \\
(0.01) \\
\end{array}$ & $\begin{array}{l}-0.19 * * * * \\
(0.01)\end{array}$ & $\begin{array}{l}-0.20 * * * \\
(0.01)\end{array}$ & $\begin{array}{l}-0.15^{* * * *} \\
(0.01) \\
\end{array}$ \\
\hline Children(0-4) & $\begin{array}{l}-0.37 \text { **** } \\
(0.02) \\
\end{array}$ & $\begin{array}{l}-0.40 \text { **** } \\
(0.02)\end{array}$ & $\begin{array}{l}-0.40 \text { **** } \\
(0.02) \\
\end{array}$ & $\begin{array}{l}-0.37 * * * * \\
(0.02) \\
\end{array}$ & $\begin{array}{l}-0.41 \text { **** } \\
(0.01) \\
\end{array}$ & $\begin{array}{l}-0.39 * * * * \\
(0.01) \\
\end{array}$ & $\begin{array}{l}-0.43 * * * \\
(0.01) \\
\end{array}$ & $\begin{array}{l}-0.45 * * * \\
(0.01) \\
\end{array}$ & $\begin{array}{l}-0.44 * * * * \\
(0.01) \\
\end{array}$ & $\begin{array}{l}-0.45 * * * * \\
(0.01) \\
\end{array}$ & $\begin{array}{l}-0.41 \text { **** } \\
(0.01) \\
\end{array}$ \\
\hline Children(5-11) & $\begin{array}{l}-0.18 * * * * \\
(0.01) \\
\end{array}$ & $\begin{array}{l}-0.18 * * * \\
(0.01)\end{array}$ & $\begin{array}{l}-0.20 * * * * \\
(0.01) \\
\end{array}$ & $\begin{array}{l}-0.24 * * * * \\
(0.01)\end{array}$ & $\begin{array}{l}-0.19 * * * * \\
(0.01)\end{array}$ & $\begin{array}{l}-0.17 * * * * \\
(0.01)\end{array}$ & $\begin{array}{l}-0.17 \text { *** } \\
(0.01)\end{array}$ & $\begin{array}{l}-0.22 * * * * \\
(0.01)\end{array}$ & $\begin{array}{l}-0.23 * * * \\
(0.01)\end{array}$ & $\begin{array}{l}-0.20 * * * * \\
(0.01)\end{array}$ & $\begin{array}{l}-0.17 * * * \\
(0.01)\end{array}$ \\
\hline Children(12-14) & $\begin{array}{l}-0.09 * * * * \\
(0.02)\end{array}$ & $\begin{array}{l}-0.09 * * * \\
(0.02)\end{array}$ & $\begin{array}{l}-0.11 * * * * \\
(0.02)\end{array}$ & $\begin{array}{l}-0.12 * * * \\
(0.02)\end{array}$ & $\begin{array}{l}-0.07 * * * \\
(0.01)\end{array}$ & $\begin{array}{l}-0.09 * * * \\
(0.01)\end{array}$ & $\begin{array}{l}-0.07 * * * * \\
(0.01)\end{array}$ & $\begin{array}{l}-0.05 * * * \\
(0.01)\end{array}$ & $\begin{array}{l}-0.06 * * * \\
(0.01)\end{array}$ & $\begin{array}{l}-0.06 * * * \\
(0.01)\end{array}$ & $\begin{array}{l}-0.04 * * * \\
(0.01)\end{array}$ \\
\hline Husband primary grad. & $\begin{array}{l}-0.09 \\
(0.07) \\
\end{array}$ & $\begin{array}{l}-\mathbf{0 . 1 8} * * * * \\
(0.07)\end{array}$ & $\begin{array}{l}-0.08 \\
(0.08) \\
\end{array}$ & $\begin{array}{l}-0.10 \\
(0.08) \\
\end{array}$ & $\begin{array}{l}0.04 \\
(0.07) \\
\end{array}$ & $\begin{array}{l}-0.11 * \\
(0.06)\end{array}$ & $\begin{array}{l}-0.10 * \\
(0.06) \\
\end{array}$ & $\begin{array}{l}-0.05 \\
(0.06) \\
\end{array}$ & $\begin{array}{l}-0.10 * \\
(0.06) \\
\end{array}$ & $\begin{array}{l}-0.05 \\
(0.06) \\
\end{array}$ & $\begin{array}{l}-0.09 * * \\
(0.04)\end{array}$ \\
\hline Husband middle grad. & $\begin{array}{l}-0.22 * * * * \\
(0.07)\end{array}$ & $\begin{array}{l}-0.28 * * * * \\
(0.08)\end{array}$ & $\begin{array}{l}-0.19 * * \\
(0.08)\end{array}$ & $\begin{array}{l}-0.18 * * \\
(0.08)\end{array}$ & $\begin{array}{l}-0.05 \\
(0.07)\end{array}$ & $\begin{array}{l}-0.17 * * * * \\
(0.06)\end{array}$ & $\begin{array}{l}-0.16 \text { **** } \\
(0.06)\end{array}$ & $\begin{array}{l}-0.06 \\
(0.07)\end{array}$ & $\begin{array}{l}-0.10^{*} \\
(0.06)\end{array}$ & $\begin{array}{l}-0.04 \\
(0.06)\end{array}$ & $\begin{array}{l}-0.15^{* * * *} \\
(0.04)\end{array}$ \\
\hline Husband high grad. & $\begin{array}{l}-0.22 * * * * \\
(0.07) \\
\end{array}$ & $\begin{array}{l}-\mathbf{0 . 3 3} * * * * \\
(\mathbf{0 . 0 8})\end{array}$ & $\begin{array}{l}-0.21 * * * * \\
(0.08) \\
\end{array}$ & $\begin{array}{l}-0.22 * * * \\
(0.08) \\
\end{array}$ & $\begin{array}{l}-0.08 \\
(0.07)\end{array}$ & $\begin{array}{l}-0.24 * * * * \\
(0.06) \\
\end{array}$ & $\begin{array}{l}-0.19 * * * \\
(0.06)\end{array}$ & $\begin{array}{l}-0.19 * * * * \\
(0.06) \\
\end{array}$ & $\begin{array}{l}-0.16 * * * * \\
(0.06)\end{array}$ & $\begin{array}{l}-0.13 * * \\
(0.06) \\
\end{array}$ & $\begin{array}{l}-0.25 * * * \\
(0.04)\end{array}$ \\
\hline Husband college grad. & $\begin{array}{l}-0.15 * * \\
(0.08) \\
\end{array}$ & $\begin{array}{l}-0.28 * * * * \\
(0.08) \\
\end{array}$ & $\begin{array}{l}-0.23 * * * * \\
(0.08) \\
\end{array}$ & $\begin{array}{l}-0.16 * * \\
(0.09) \\
\end{array}$ & $\begin{array}{l}-0.09 \\
(0.08) \\
\end{array}$ & $\begin{array}{l}-0.18 * * * * \\
(0.06) \\
\end{array}$ & $\begin{array}{l}\mathbf{- 0 . 1 7} \text { **** } \\
\mathbf{( 0 . 0 6 )} \\
\end{array}$ & $\begin{array}{l}-0.17 \text { **** } \\
(0.07) \\
\end{array}$ & $\begin{array}{l}-0.25 * * * * \\
(0.06) \\
\end{array}$ & $\begin{array}{l}-0.17 * * * * \\
(0.06) \\
\end{array}$ & $\begin{array}{l}-0.33 * * * \\
(0.05) \\
\end{array}$ \\
\hline Wife primary grad. & $\begin{array}{l}0.17 * * * \\
(0.04)\end{array}$ & $\begin{array}{l}0.31 * * * \\
(\mathbf{0 . 0 4 )}\end{array}$ & $\begin{array}{l}0.22 * * * \\
(0.04)\end{array}$ & $\begin{array}{l}0.12 * * * * \\
(0.04)\end{array}$ & $\begin{array}{l}0.19 * * * \\
(0.03)\end{array}$ & $\begin{array}{l}0.16 * * * * \\
(0.03)\end{array}$ & $\begin{array}{l}0.20 * * * \\
(\mathbf{0 . 0 3})\end{array}$ & $\begin{array}{l}0.22 * * * \\
(\mathbf{0 . 0 3})\end{array}$ & $\begin{array}{l}0.25 * * * * \\
(0.03)\end{array}$ & $\begin{array}{l}\mathbf{0 . 2 9} * * * \\
(0.03)\end{array}$ & $\begin{array}{l}0.19 * * * \\
(0.02)\end{array}$ \\
\hline Wife middle grad. & $\begin{array}{l}\text { 0.53**** } \\
(0.05)\end{array}$ & $\begin{array}{l}0.53 * * * \\
(\mathbf{0 . 0 5}) \\
\end{array}$ & $\begin{array}{l}0.51 * * * * \\
(0.05) \\
\end{array}$ & $\begin{array}{l}0.40 * * * \\
(0.05)\end{array}$ & $\begin{array}{l}0.49 * * * \\
(0.04)\end{array}$ & $\begin{array}{l}0.44 * * * \\
(0.04)\end{array}$ & $\begin{array}{l}0.45 * * * \\
(0.04)\end{array}$ & $\begin{array}{l}0.48 * * * * \\
(0.04) \\
\end{array}$ & $\begin{array}{l}0.45 * * * \\
(0.04) \\
\end{array}$ & $\begin{array}{l}0.41 * * * \\
(0.03) \\
\end{array}$ & $\begin{array}{l}0.26 * * * * \\
(0.03)\end{array}$ \\
\hline Wife high grad. & $\begin{array}{l}1.00 \text { *** } \\
(0.04)\end{array}$ & $\begin{array}{l}1.05 * * * \\
(0.05)\end{array}$ & $\begin{array}{l}0.90 * * * * \\
(0.04)\end{array}$ & $\begin{array}{l}0.76 * * * \\
(0.04)\end{array}$ & $\begin{array}{l}0.89 * * * \\
(0.04)\end{array}$ & $\begin{array}{l}0.77 * * * \\
(0.03)\end{array}$ & $\begin{array}{l}0.78 * * * \\
(0.03)\end{array}$ & $\begin{array}{l}0.81 * * * \\
(0.03) \\
\end{array}$ & $\begin{array}{l}0.85 * * * \\
(0.03)\end{array}$ & $\begin{array}{l}0.76 \text { **** } \\
(\mathbf{0 . 0 3})\end{array}$ & $\begin{array}{l}0.57 * * * \\
(0.02)\end{array}$ \\
\hline Wife college grad. & $\begin{array}{l}2.34 * * * * \\
(0.05)\end{array}$ & $\begin{array}{l}2.41 * * * \\
(0.05)\end{array}$ & $\begin{array}{l}2.15 * * * \\
(0.05)\end{array}$ & $\begin{array}{l}2.06 * * * \\
(0.05)\end{array}$ & $\begin{array}{l}2.22 * * * \\
(0.04)\end{array}$ & $\begin{array}{l}2.05 * * * \\
(0.04)\end{array}$ & $\begin{array}{l}2.04 * * * \\
(0.04)\end{array}$ & $\begin{array}{l}2.11 * * * \\
(0.04)\end{array}$ & $\begin{array}{l}2.13 * * * * \\
(0.04)\end{array}$ & $\begin{array}{l}2.07 * * * * \\
(0.03)\end{array}$ & $\begin{array}{l}1.86 * * * * \\
(0.03)\end{array}$ \\
\hline Other adults in household & $\begin{array}{l}\text { 0.10*** } \\
(0.03) \\
\end{array}$ & $\begin{array}{l}0.10 * * * \\
(0.03)\end{array}$ & $\begin{array}{l}0.09 * * * \\
(0.02) \\
\end{array}$ & $\begin{array}{l}0.14 * * * * \\
(0.02)\end{array}$ & $\begin{array}{l}\mathbf{0 . 0 8} * * * * \\
(0.02)\end{array}$ & $\begin{array}{l}\mathbf{0 . 0 7 * * *} \\
(\mathbf{0 . 0 2}) \\
\end{array}$ & $\begin{array}{l}0.003 \\
(0.02) \\
\end{array}$ & $\begin{array}{ll}0.01 \\
(0.02) \\
\end{array}$ & $\begin{array}{l}-0.02 \\
(0.02) \\
\end{array}$ & $\begin{array}{l}\mathbf{0 . 0 3} * * \\
(\mathbf{0 . 0 2}) \\
\end{array}$ & $\begin{array}{l}0.01 \\
(0.02) \\
\end{array}$ \\
\hline $\begin{array}{l}\text { GDP per capita } \\
\text { (In 1000) }\end{array}$ & NA & NA & NA & NA & $\begin{array}{l}0.08 * * * \\
(0.0006)\end{array}$ & $\begin{array}{l}0.07 * * * \\
(0.0007)\end{array}$ & $\begin{array}{l}0.06 * * * \\
(0.0008)\end{array}$ & $\begin{array}{l}0.04 * * * \\
(0.0007)\end{array}$ & $\begin{array}{l}0.04 * * * \\
(0.0008)\end{array}$ & $\begin{array}{l}\mathbf{0 . 0 1} * * * \\
(0.0007)\end{array}$ & $\begin{array}{l}-0.02 * * * \\
(0.0006)\end{array}$ \\
\hline Log Likelihood & -9257.2 & -9568.3 & -10397.5 & -10016.9 & -13759.5 & -14640.4 & -15392.8 & -15412.8 & -16236.4 & -17909.1 & -23442.7 \\
\hline Pseudo R2 & 0.24 & 0.23 & 0.20 & 0.21 & 0.21 & 0.20 & 0.19 & 0.20 & 0.20 & 0.19 & 0.14 \\
\hline $\mathbf{N}$ & 30036 & 30164 & 29535 & 29340 & 41539 & 41831 & 42064 & 41892 & 41770 & 42831 & 48060 \\
\hline
\end{tabular}


Table 2b Marginal Effects

\begin{tabular}{|c|c|c|c|c|c|c|c|c|c|c|c|}
\hline Variable & 2000 & 2001 & 2002 & 2003 & 2004 & 2005 & 2006 & 2007 & 2008 & 2009 & 2010 \\
\hline Husband unemployed & $\mathbf{0 . 0 8} * * *$ & $\mathbf{0 . 0 8} * * *$ & $0.07 * * *$ & $0.08 * * *$ & $0.06 * * * *$ & $0.04 * * *$ & $0.06 * * *$ & $0.05^{* * * *}$ & $0.05 * * *$ & $\mathbf{0 . 0 6} * * *$ & $0.04 * * *$ \\
\hline Husband underemployed & $0.02 * * *$ & $0.04 * * *$ & -0.003 & $0.06 * * *$ & $0.04 * * *$ & $0.08 * * *$ & $0.07 * * *$ & $0.05 * * *$ & $0.08 * * *$ & $0.10 * * *$ & $0.13 * * *$ \\
\hline Husband's age & $\mathbf{0 . 0 2} * * *$ & $\mathbf{0 . 0 1} * * *$ & $\mathbf{0 . 0 1} * * *$ & $\mathbf{0 . 0 1} * * *$ & $0.009 * * *$ & $\mathbf{0 . 0 1} * * *$ & $\mathbf{0 . 0 1} * * *$ & $\mathbf{0 . 0 1 * * * *}$ & $\mathbf{0 . 0 2} * * *$ & $0.01 * * *$ & $\mathbf{0 . 0 1} * * *$ \\
\hline $\begin{array}{l}\text { Husband's age squared } \\
\text { (in }\end{array}$ & $-0.03 * * *$ & $-\mathbf{0 . 0 2} * * *$ & $-0.02 * * *$ & $-0.02 * * *$ & $-\mathbf{0 . 0 1} * * *$ & $-0.01 * * *$ & $-0.02 * * *$ & $-0.01 * * *$ & $-0.02 * * *$ & $-0.02 * * *$ & $-0.02 * * *$ \\
\hline Wife's age & $\mathbf{0 . 0 1} * *$ & $\mathbf{0 . 0 1 * *}$ & $\mathbf{0 . 0 2} * * *$ & $\mathbf{0 . 0 2} * * *$ & $0.02 * * *$ & $\mathbf{0 . 0 3} * * *$ & $\mathbf{0 . 0 2} * * *$ & $\mathbf{0 . 0 3} * * *$ & $\mathbf{0 . 0 3 * * *}$ & $\mathbf{0 . 0 3} * * *$ & $\mathbf{0 . 0 3} * * *$ \\
\hline $\begin{array}{l}\text { Wife's age squared } \\
\text { (in 100) }\end{array}$ & $-0.01 * *$ & $-0.02 * *$ & $-0.04 * * *$ & $-0.03 * * *$ & $-0.04 * * *$ & $-0.04 * * *$ & $-0.03 * * *$ & $-0.05^{* * * *}$ & $-0.04 * * *$ & $-0.05 * * *$ & $-0.04 * * *$ \\
\hline Children(0-4) & $-0.06 * * *$ & $-\mathbf{0 . 0 7} * * *$ & $-\mathbf{0 . 0 8} * * *$ & $-0.07 * * *$ & $-\mathbf{- 0 . 0 7 * * *}$ & $-\mathbf{0 . 0 8}$ **** & $-0.09 * * *$ & $-0.09 * * *$ & $-0.10 * * *$ & $-0.11 * * *$ & $-0.12 * * *$ \\
\hline Children(5-11) & $-0.03 * * *$ & $-0.03 * * *$ & $-0.04 * * *$ & $-0.04 * * *$ & $-0.03 * * *$ & $-0.03 * * *$ & $-\mathbf{0 . 0 3} * * *$ & $-0.04 * * *$ & $-\mathbf{0 . 0 5} * * *$ & $-0.05 * * *$ & $-0.05 * * *$ \\
\hline Children(12-14) & $-0.01 * * *$ & $-0.01 * * *$ & $-\mathbf{0 . 0 2} * * *$ & $-0.02 * * *$ & $-0.01 * * *$ & $-0.01 * * *$ & $-0.01 * * *$ & $-0.01 * * *$ & $-0.01 * * *$ & $-0.01 * * *$ & $-0.01 * * *$ \\
\hline Husband primary grad. & -0.01 & $-0.03 * * *$ & -0.01 & -0.02 & 0.009 & $-0.02 *$ & $-0.02 *$ & -0.01 & $-0.02 *$ & -0.01 & $-0.02 * *$ \\
\hline Husband middle grad. & $-\mathbf{0 . 0 3} * * *$ & $-0.04 * * *$ & $-\mathbf{0 . 0 3} * *$ & $-0.03 * *$ & -0.01 & $-0.03 * * *$ & $-\mathbf{0 . 0 3} * * *$ & -0.01 & $-0.02 *$ & -0.01 & $-0.04 * * *$ \\
\hline Husband high grad. & $-0.03 * * *$ & $-0.05 * * *$ & $-\mathbf{0 . 0 4} * * *$ & $-0.04 * * *$ & -0.01 & $-0.04 * * *$ & $\mathbf{- 0 . 0 3} * * *$ & $-0.04 * * *$ & $\mathbf{- 0 . 0 3} * * *$ & $-0.03 * *$ & $-0.07 * *$ \\
\hline Husband college grad. & $-\mathbf{- 0 . 0 2} * *$ & $-0.04 * * *$ & $\mathbf{- 0 . 0 4} * * *$ & $-\mathbf{- 0 . 0 3} * *$ & -0.01 & $-0.03 * * *$ & $-\mathbf{0 . 0 3} * * *$ & $-0.03 * * *$ & $-0.05 * * *$ & $-0.04 * * *$ & $-0.09 * * *$ \\
\hline Wife primary grad. & $\mathbf{0 . 0 3} * * *$ & $\mathbf{0 . 0 5} * * *$ & $0.04 * * *$ & $\mathbf{0 . 0 2} * * *$ & $0.03 * * *$ & $\mathbf{0 . 0 3} * * *$ & $0.04 * * *$ & $0.04 * * *$ & $\mathbf{0 . 0 6} * * *$ & $\mathbf{0 . 0 7 * * *}$ & $\mathbf{0 . 0 5} * * *$ \\
\hline Wife middle grad. & $0.12 * * *$ & $0.12 * * *$ & $0.13 * * *$ & $0.09 * * *$ & $0.11 * * *$ & $0.11 * * *$ & $0.11 * * *$ & $0.12 * * *$ & $0.12 * * *$ & $0.12 * * *$ & $0.08 * * *$ \\
\hline Wife high grad. & $0.26 * * *$ & $\mathbf{0 . 2 8} * * *$ & $0.25 * * *$ & $\mathbf{0 . 1 9} * * *$ & $0.23 * * *$ & $\mathbf{0 . 2 0} * * *$ & $\mathbf{0 . 2 1} * * *$ & $0.22 * * *$ & $0.25 * * *$ & $0.24 * * *$ & $\mathbf{0 . 1 9} * * *$ \\
\hline Wife college grad. & $0.74 * * *$ & $0.76 * * *$ & $0.70 * * *$ & $0.67 * * *$ & $0.71 * * *$ & $0.67 * * *$ & $0.67 * * *$ & $0.69 * * *$ & $\mathbf{0 . 7 0 * * *}$ & $0.69 * * *$ & $0.64 * * *$ \\
\hline Other adults in household & $\mathbf{0 . 0 1} * * *$ & 0.01** & $\mathbf{0 . 0 2} * * *$ & $\mathbf{0 . 0 2} * * *$ & $0.01 * * *$ & $0.01 * * *$ & 0.0007 & 0.004 & -0.005 & $0.01 * *$ & 0.005 \\
\hline $\begin{array}{l}\text { GDP per capita } \\
\text { (in 1000) }\end{array}$ & NA & NA & NA & NA & $0.01 * * *$ & 0.01*** & $0.01 * * *$ & $0.01 * * *$ & $0.01 * * *$ & $0.0003 * * *$ & $-0.0007 * * *$ \\
\hline
\end{tabular}

***indicates 1 percent, $* *$ indicates 5 percent significance, $*$ indicates 1 percent significance. 
Table 3. Tobit Results. Dependent Variable: Wife's total work hours.

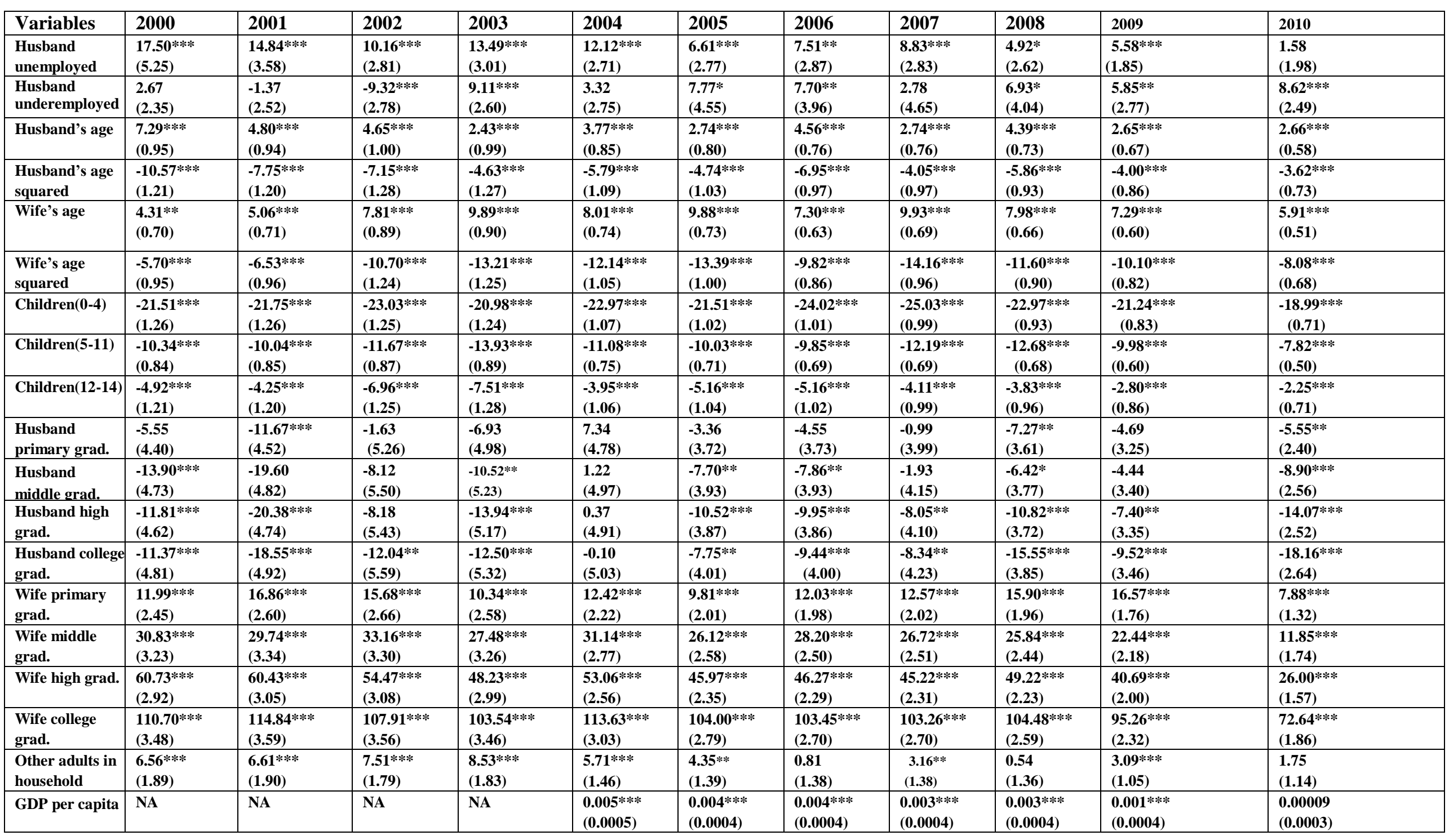




\begin{tabular}{|c|c|c|c|c|c|c|}
\hline \multicolumn{7}{|c|}{ Table 4. Pooled Sample Probit Results } \\
\hline $\begin{array}{l}\text { Explanatory } \\
\text { Variables } \\
\end{array}$ & Coefficients & $\begin{array}{l}\text { Marginal } \\
\text { effects }\end{array}$ & Coefficients & $\begin{array}{l}\text { Marginal } \\
\text { effects }\end{array}$ & Coefficients & $\begin{array}{l}\text { Marginal } \\
\text { Effects }\end{array}$ \\
\hline $\begin{array}{l}\text { Husband } \\
\text { unemployed }\end{array}$ & $\begin{array}{l}0.24 * * * \\
(0.01) \\
\end{array}$ & 0.06 & $\begin{array}{l}0.24 * * * \\
(0.01)\end{array}$ & 0.06 & $\begin{array}{l}0.22 * * * \\
(0.01)\end{array}$ & 0.05 \\
\hline $\begin{array}{l}\text { Husband } \\
\text { underemployed }\end{array}$ & & & $\begin{array}{l}0.20 * * * \\
(0.01)\end{array}$ & 0.05 & $\begin{array}{l}0.30 * * * \\
(0.02)\end{array}$ & 0.08 \\
\hline Husband's age & $\begin{array}{l}0.07 * * * \\
(0.004)\end{array}$ & 0.01 & $\begin{array}{l}0.07 * * * * \\
(0.004)\end{array}$ & 0.01 & $\begin{array}{l}0.06 * * * * \\
(0.005)\end{array}$ & 0.01 \\
\hline $\begin{array}{l}\text { Husband's age } \\
\text { squared/100 }\end{array}$ & $\begin{array}{l}-0.10 * * * \\
(0.005)\end{array}$ & -0.02 & $\begin{array}{l}-0.10 * * * \\
(0.005)\end{array}$ & -0.02 & $\begin{array}{l}-0.09 * * * \\
(0.007)\end{array}$ & -0.02 \\
\hline Wife's age & $\begin{array}{l}0.12 * * * \\
(0.003)\end{array}$ & 0.02 & $\begin{array}{l}0.12 * * * * \\
(0.003)\end{array}$ & 0.02 & $\begin{array}{l}0.13 * * * * \\
(0.006)\end{array}$ & 0.03 \\
\hline $\begin{array}{l}\text { Wife's age } \\
\text { squared/100 }\end{array}$ & $\begin{array}{l}-(0.18 * * * \\
(0.004)\end{array}$ & -0.04 & $\begin{array}{l}-0.18 * * * * \\
(0.004)\end{array}$ & -0.04 & $\begin{array}{l}-0.19 * * * \\
(0.008)\end{array}$ & -0.04 \\
\hline Children(0-4) & $\begin{array}{l}-0.42 * * * * \\
(0.005) \\
\end{array}$ & $\begin{array}{l}-0.09 \\
\end{array}$ & $\begin{array}{l}-0.42 * * * \\
(0.005) \\
\end{array}$ & -0.09 & $\begin{array}{l}-0.41 * * * \\
(0.006) \\
\end{array}$ & -0.09 \\
\hline Children(5-11) & $\begin{array}{l}-0.19 * * * \\
(0.003)\end{array}$ & $\begin{array}{l}-0.04 \\
\end{array}$ & $\begin{array}{l}-0.19 * * * \\
(0.003)\end{array}$ & -0.04 & $\begin{array}{l}-0.18 * * * \\
(0.004)\end{array}$ & -0.04 \\
\hline Children(12-14) & $\begin{array}{l}-0.07 * * * * \\
(0.005)\end{array}$ & -0.01 & $\begin{array}{l}-0.07 * * * \\
(0.005)\end{array}$ & -0.01 & $\begin{array}{l}-0.05 * * * * \\
(0.006)\end{array}$ & -0.01 \\
\hline $\begin{array}{l}\text { Husband } \\
\text { primary grad. }\end{array}$ & $\begin{array}{l}-0.08 * * * * \\
(0.01)\end{array}$ & -0.01 & $\begin{array}{l}-0.07 * * * * \\
(0.01)\end{array}$ & -0.01 & $\begin{array}{l}-0.10 * * * \\
(0.02)\end{array}$ & $\begin{array}{c}-0.02 \\
\end{array}$ \\
\hline $\begin{array}{l}\text { Husband } \\
\text { middle grad. }\end{array}$ & $\begin{array}{l}-0.14 * * * \\
(0.02) \\
\end{array}$ & -0.03 & $\begin{array}{l}-0.13 * * * \\
(0.02) \\
\end{array}$ & -0.02 & $\begin{array}{l}-0.14 * * * \\
(0.02) \\
\end{array}$ & -0.03 \\
\hline $\begin{array}{l}\text { Husband high } \\
\text { grad. }\end{array}$ & $\begin{array}{l}-0.21 * * * \\
(0.02) \\
\end{array}$ & $\begin{array}{c}-0.04 \\
\end{array}$ & $\begin{array}{l}-0.19 * * * \% \\
(0.02) \\
\end{array}$ & -0.04 & $\begin{array}{l}-0.21 * * * \\
(0.02) \\
\end{array}$ & -0.04 \\
\hline $\begin{array}{l}\text { Husband } \\
\text { college grad. }\end{array}$ & $\begin{array}{l}-0.22 * * * * \\
(0.02)\end{array}$ & $\begin{array}{c}-0.04 \\
\end{array}$ & $\begin{array}{l}-0.21 \text { *** } \\
(0.02)\end{array}$ & -0.04 & $\begin{array}{l}-0.24 * * * \\
(0.02)\end{array}$ & -0.05 \\
\hline $\begin{array}{l}\text { Wife primary } \\
\text { grad. }\end{array}$ & $\begin{array}{l}0.22 * * * \\
(0.01)\end{array}$ & 0.04 & $\begin{array}{l}0.22 * * * * \\
(0.01)\end{array}$ & 0.05 & $\begin{array}{l}0.18 * * * \\
(0.01)\end{array}$ & 0.04 \\
\hline $\begin{array}{l}\text { Wife middle } \\
\text { grad. }\end{array}$ & $\begin{array}{l}0.44 * * * \\
(0.01)\end{array}$ & 0.11 & $\begin{array}{l}0.44 * * * \\
(0.01)\end{array}$ & 0.11 & $\begin{array}{l}\mathbf{0 . 3 8} * * * \\
(\mathbf{0 . 0 1})\end{array}$ & 0.10 \\
\hline Wife high grad. & $\begin{array}{l}0.81 * * * \\
(0.01)\end{array}$ & 0.23 & $\begin{array}{l}0.82 * * * \\
(0.01)\end{array}$ & 0.23 & $\begin{array}{l}0.73 * * * \\
(0.01) \\
\end{array}$ & 0.21 \\
\hline $\begin{array}{l}\text { Wife college } \\
\text { grad. }\end{array}$ & $\begin{array}{l}2.10 * * * \\
(0.01)\end{array}$ & 0.69 & $\begin{array}{l}2.11 * * * \\
(0.01)\end{array}$ & 0.69 & $\begin{array}{l}2.02 * * * \\
(0.01)\end{array}$ & 0.67 \\
\hline $\begin{array}{l}\text { Other adults in } \\
\text { household }\end{array}$ & $\begin{array}{l}0.04 * * * \\
(0.007)\end{array}$ & 0.01 & $\begin{array}{l}0.04 * * * * \\
(0.007)\end{array}$ & 0.01 & $\begin{array}{l}0.02 * * * * \\
(0.008)\end{array}$ & 0.005 \\
\hline $\begin{array}{l}\text { Regional } \\
\text { Unemployment }(\%)\end{array}$ & & & & & $\begin{array}{l}-2.75 * * * \\
(0.10)\end{array}$ & -0.64 \\
\hline $\begin{array}{l}\text { GDP per capita } \\
\text { (in 1000) }\end{array}$ & & & & & $\begin{array}{c}0.07 * * * * \\
(0.0003) \\
\end{array}$ & 0.01 \\
\hline Intercept & $\begin{array}{l}-4.41 * * * \\
(0.07)\end{array}$ & & $\begin{array}{l}-4.46 * * * * \\
(0.07)\end{array}$ & & $\begin{array}{l}-4.21 \text { **** } \\
(0.08)\end{array}$ & \\
\hline Year dummies & Yes & & Yes & & Yes & \\
\hline Log-Likelihood & -157031.54 & & -156930.53 & & -116892 & \\
\hline Pseudo R2 & 0.20 & & 0.20 & & 0.19 & \\
\hline $\mathbf{N}$ & 419062 & & 419062 & & 299987 & \\
\hline
\end{tabular}

***indicates 1 percent significance, $* *$ indicates 5 percent significance, $*$ indicates 1 percent significance. 
Table 5. Pooled Sample Tobit Results

\begin{tabular}{|c|c|c|c|}
\hline Explanatory variables & 1 & 2 & 3 \\
\hline Husband unemployed & $\begin{array}{l}\text { 7.76**** } \\
(\mathbf{0 . 8 0})\end{array}$ & $\begin{array}{l}\text { 7.84**** } \\
(\mathbf{0 . 8 0 )}\end{array}$ & $\begin{array}{l}6.98 * * * \\
(0.92)\end{array}$ \\
\hline Husband underemployed & & $\begin{array}{l}2.12 * * * \\
(0.87)\end{array}$ & $\begin{array}{l}6.33 * * * \\
(1.24)\end{array}$ \\
\hline Husband's age & $\begin{array}{l}3.76 * * * \\
(0.23)\end{array}$ & $\begin{array}{l}3.76 * * * \\
(0.23)\end{array}$ & $\begin{array}{l}3.05 * * * \\
(0.27)\end{array}$ \\
\hline Husband's age squared (in 100) & $\begin{array}{l}-5.62 * * * \\
(0.30)\end{array}$ & $\begin{array}{l}-5.63 * * * \\
(0.30)\end{array}$ & $\begin{array}{l}-4.51 * * * \\
(0.34)\end{array}$ \\
\hline Wife's age & $\begin{array}{l}7.35 * * * \\
(0.20)\end{array}$ & $\begin{array}{l}\text { 7.35**** } \\
(\mathbf{0 . 2 0 )}\end{array}$ & $\begin{array}{l}7.64 * * * \\
(0.24)\end{array}$ \\
\hline $\begin{array}{l}\text { Wife's age squared } \\
\text { (in } 100 \text { ) }\end{array}$ & $\begin{array}{l}-10.12 * * * \\
(0.28)\end{array}$ & $\begin{array}{l}-10.12 * * * \\
(0.28)\end{array}$ & $\begin{array}{l}-10.63 * * * \\
(0.33)\end{array}$ \\
\hline Children(0-4) & $\begin{array}{l}-22.32 * * * \\
(0.30)\end{array}$ & $\begin{array}{l}-22.33 * * * \\
(0.30)\end{array}$ & $\begin{array}{l}-21.23 * * * \\
(0.34)\end{array}$ \\
\hline Children(5-11) & $\begin{array}{l}-10.69 * * * \\
(0.21)\end{array}$ & $\begin{array}{l}-10.70 * * * \\
(0.21)\end{array}$ & $\begin{array}{l}-9.60 * * * \\
(0.24)\end{array}$ \\
\hline Children(12-14) & $\begin{array}{l}-4.37 * * * \\
(0.30)\end{array}$ & $\begin{array}{l}-4.37 * * * \\
(0.30) \\
\end{array}$ & $\begin{array}{l}-3.17 * * * \\
(0.35) \\
\end{array}$ \\
\hline Husband primary grad. & $\begin{array}{l}-4.01 * * * \\
(1.13)\end{array}$ & $\begin{array}{l}-3.94 * * * \\
(1.13)\end{array}$ & $\begin{array}{l}-5.40 * * * \\
(1.29)\end{array}$ \\
\hline Husband middle grad. & $\begin{array}{l}-7.39 * * * \\
(1.19)\end{array}$ & $\begin{array}{l}-7.30 * * * \\
(1.19)\end{array}$ & $\begin{array}{l}-7.60 * * * \\
(1.36)\end{array}$ \\
\hline Husband high grad. & $\begin{array}{l}-10.43 * * * \\
(1.17)\end{array}$ & $\begin{array}{l}-10.32 * * * \\
(1.17)\end{array}$ & $\begin{array}{l}-11.30 * * * \\
(1.34)\end{array}$ \\
\hline Husband college grad. & $\begin{array}{l}-12.04 * * * \\
(1.22)\end{array}$ & $\begin{array}{l}-11.92 * * * \\
(1.22)\end{array}$ & $\begin{array}{l}-12.88 * * * \\
(1.39)\end{array}$ \\
\hline Wife primary grad. & $\begin{array}{l}13.17 * * * \\
(0.60)\end{array}$ & $\begin{array}{l}13.21 * * * \\
(0.60)\end{array}$ & $\begin{array}{l}9.71 * * * \\
(0.69)\end{array}$ \\
\hline Wife middle grad. & $\begin{array}{l}25.68 * * * \\
(0.77)\end{array}$ & $\begin{array}{l}25.71 * * * \\
(0.77)\end{array}$ & $\begin{array}{l}\text { 21.11**** } \\
(0.87)\end{array}$ \\
\hline Wife high grad. & $\begin{array}{l}46.51 * * * \\
(0.70)\end{array}$ & $\begin{array}{l}46.56 * * * \\
(0.70)\end{array}$ & $\begin{array}{l}40.09 * * * \\
(0.80)\end{array}$ \\
\hline Wife college grad. & $\begin{array}{l}100.93 * * * \\
(0.82)\end{array}$ & $\begin{array}{l}100.99 * * * \\
(0.82)\end{array}$ & $\begin{array}{l}94.84 * * * \\
(0.93)\end{array}$ \\
\hline Other adults in household & $\begin{array}{l}3.67 * * * \\
(0.43)\end{array}$ & $\begin{array}{l}3.67 * * * \\
(0.43)\end{array}$ & $\begin{array}{l}2.62 * * * \\
(0.48)\end{array}$ \\
\hline Regional Unemployment $(\%)$ & & & $\begin{array}{l}-180.11 * * * \\
(5.66)\end{array}$ \\
\hline GDP per capita & & & $\begin{array}{l}0.004 * * * \\
(0.00001)\end{array}$ \\
\hline Intercept & $\begin{array}{l}-259.09 * * * \\
(4.14)\end{array}$ & $\begin{array}{l}-259.53 * * * \\
(4.14)\end{array}$ & $\begin{array}{l}-238.96 * * * * \\
(4.78)\end{array}$ \\
\hline Year Dummies & Yes & Yes & Yes \\
\hline Log-Likelihood & -447495.51 & -447492.6 & -338865 \\
\hline Pseudo R2 & 0.06 & 0.06 & 0.06 \\
\hline $\mathbf{N}$ & 419062 & 419062 & 299987 \\
\hline
\end{tabular}

***indicates 1 percent significance, $* *$ indicates 5 percent significance, $*$ indicates 1 percent significance. 
Table 6a. Panel Statistics

\begin{tabular}{|l|l|l|l|l|l|l|}
\hline & $2004-2005$ & $2005-2006$ & $2006-2007$ & $2007-2008$ & $2008-2009$ & $2009-2010$ \\
\hline LFP & & & & & & \\
\hline $\begin{array}{l}\text { Number of } \\
\text { wives in labor } \\
\text { force at t-1 }\end{array}$ & 5573 & 6016 & 6176 & 6843 & 7549 & 9510 \\
\hline $\begin{array}{l}\text { Number of } \\
\text { wives in labor } \\
\text { force at t }\end{array}$ & 6307 & 6847 & 7034 & 7721 & 8631 & 10894 \\
\hline Unemployed & & 542 & 555 & 694 & 1342 & 818 \\
\hline $\begin{array}{l}\text { Number of } \\
\text { husbands who } \\
\text { involuntarily } \\
\text { lost his job at } \\
\text { time t }\end{array}$ & 585 & 39915 & 40114 & 40073 & 40565 & 43417 \\
\hline $\begin{array}{l}\text { Number of } \\
\text { Obs. }\end{array}$ & 39483 & & & & & \\
\hline
\end{tabular}

Table 6b. Panel Results

Sample: Husband is employed at time t-1. OLS regression. Unemployed Husband=1 if husband is laid off or fired in time t, 0 otherwise.

\begin{tabular}{|c|c|c|c|c|c|c|}
\hline $\begin{array}{l}\text { Dependent } \\
\text { Variable: } \\
\text { Change in } \\
\text { LFPwife }\end{array}$ & 2005 & 2006 & 2007 & 2008 & 2009 & 2010 \\
\hline $\begin{array}{l}\text { Unemployed } \\
\text { Husband } \\
\text { (involuntary) }\end{array}$ & $\begin{array}{l}\mathbf{0 . 0 2} * * * \\
(\mathbf{0 . 0 0 8})\end{array}$ & $\begin{array}{l}\mathbf{0 . 0 3} * * * * \\
(\mathbf{0 . 0 0 9 )}\end{array}$ & $\begin{array}{l}\mathbf{0 . 0 2} * * * * \\
(\mathbf{0 . 0 0 9 )}\end{array}$ & $\begin{array}{l}\mathbf{0 . 0 2} \text { **** } \\
(\mathbf{0 . 0 0 9 )}\end{array}$ & $\begin{array}{l}\mathbf{0 . 0 2} * * * \\
(0.007)\end{array}$ & $\begin{array}{l}\text { 0.01* } \\
(0.01)\end{array}$ \\
\hline $\mathbf{R 2}$ & 0.0001 & 0.0003 & 0.0001 & 0.0003 & 0.0004 & 0.0001 \\
\hline $\mathbf{N}$ & 39483 & 39915 & 40114 & 40073 & 40565 & 43417 \\
\hline
\end{tabular}


Table 7. Pooled sample probit and tobit estimations for subsamples of women with different education levels, 2000-2010 period.

\begin{tabular}{|c|c|c|c|c|c|c|c|c|c|c|}
\hline & \multicolumn{2}{|c|}{ No education } & \multicolumn{2}{|c|}{$\begin{array}{l}\text { Primary School } \\
\text { Graduate }\end{array}$} & \multicolumn{2}{|c|}{$\begin{array}{l}\text { Middle School } \\
\text { Graduate }\end{array}$} & \multicolumn{2}{|c|}{$\begin{array}{l}\text { High School } \\
\text { Graduate }\end{array}$} & \multicolumn{2}{|c|}{ University Graduate } \\
\hline $\begin{array}{l}\text { Explanatory } \\
\text { Variables }\end{array}$ & Probit & Tobit & Probit & Tobit & Probit & Tobit & Probit & Tobit & Probit & Tobit \\
\hline $\begin{array}{l}\text { Husband } \\
\text { unemployed }\end{array}$ & $\begin{array}{l}0.02 * * \\
(0.05)\end{array}$ & $\begin{array}{l}4.76 \\
(4.53)\end{array}$ & $\begin{array}{l}\text { 0.04** } \\
(0.01)\end{array}$ & $\begin{array}{l}\text { 10.00** } \\
(1.46)\end{array}$ & $\begin{array}{l}0.07 * * \\
(0.04)\end{array}$ & $\begin{array}{l}\text { 13.05** } \\
(3.33)\end{array}$ & $\begin{array}{l}\mathbf{0 . 0 9} * * \\
(0.03)\end{array}$ & $\begin{array}{l}\text { 9.27** } \\
(2.15)\end{array}$ & $\begin{array}{l}0.01 \\
(0.06)\end{array}$ & $\begin{array}{l}\mathbf{0 . 0 1} \\
(1.41)\end{array}$ \\
\hline $\begin{array}{l}\text { Husband } \\
\text { underemp. }\end{array}$ & $\begin{array}{l}0.04 * * \\
(0.06)\end{array}$ & $\begin{array}{l}4.97 \\
(4.96)\end{array}$ & $\begin{array}{l}0.04 * * \\
(0.01)\end{array}$ & $\begin{array}{l}5.45 * * \\
(1.55)\end{array}$ & $\begin{array}{l}0.07 * * \\
(0.04)\end{array}$ & $\begin{array}{l}7.16 \\
(3.90)\end{array}$ & $\begin{array}{l}\mathbf{0 . 0 7 * *} \\
(\mathbf{0 . 0 3})\end{array}$ & $\begin{array}{l}-0.18 \\
(2.62)\end{array}$ & $\begin{array}{l}\mathbf{0 . 0 0 0 4} \\
(0.07)\end{array}$ & $\begin{array}{l}-2.59 \\
(1.76)\end{array}$ \\
\hline $\begin{array}{l}\text { Husband's } \\
\text { age }\end{array}$ & $\begin{array}{l}\text { 0.01** } \\
(\mathbf{0 . 0 2})\end{array}$ & $\begin{array}{l}\text { 5.45** } \\
(1.63)\end{array}$ & $\begin{array}{l}\mathbf{0 . 0 1} * * \\
(0.009)\end{array}$ & $\begin{array}{l}4.96 * * \\
(0.48)\end{array}$ & $\begin{array}{l}\mathbf{0 . 0 1} * * \\
(0.01)\end{array}$ & $\begin{array}{l}3.62 * * \\
(1.02)\end{array}$ & $\begin{array}{l}\mathbf{0 . 0 2} * * \\
(0.008)\end{array}$ & $\begin{array}{l}\text { 4.82*** } \\
(0.55)\end{array}$ & $\begin{array}{l}\mathbf{0 . 0 3} * * \\
(0.01)\end{array}$ & $\begin{array}{l}1.87 * * \\
(0.29)\end{array}$ \\
\hline $\begin{array}{l}\text { Husband's } \\
\text { age squared } \\
\text { (in 100) }\end{array}$ & $\begin{array}{l}-\mathbf{- 0 . 0 1} * * \\
(\mathbf{0 . 0 2})\end{array}$ & $\begin{array}{l}-6.36 * * \\
(1.98)\end{array}$ & $\begin{array}{l}-0.01 * * \\
(0.01)\end{array}$ & $\begin{array}{l}-6.87 * * \\
(0.61)\end{array}$ & $\begin{array}{l}-0.02 * * \\
(0.01)\end{array}$ & $\begin{array}{l}-5.99 * * \\
(1.31)\end{array}$ & $\begin{array}{l}-(0.03 * * \\
(0.01)\end{array}$ & $\begin{array}{l}-8.14 * * \\
(0.72)\end{array}$ & $\begin{array}{l}-\mathbf{- 0 . 0 4 * *} \\
(0.01)\end{array}$ & $\begin{array}{l}-2.84 * * \\
(0.37)\end{array}$ \\
\hline Wife's age & $\begin{array}{l}\mathbf{0 . 0 0 6}^{* * *} \\
(0.01)\end{array}$ & $\begin{array}{l}4.61 * * \\
(1.26)\end{array}$ & $\begin{array}{l}0.01 * * \\
(0.01)\end{array}$ & $\begin{array}{l}4.36 * * \\
(0.39)\end{array}$ & $\begin{array}{l}0.02 * * \\
(0.01)\end{array}$ & $\begin{array}{l}8.93 * * \\
(0.90)\end{array}$ & $\begin{array}{l}0.05 * * \\
(0.008)\end{array}$ & $\begin{array}{l}\text { 12.75** } \\
(0.52)\end{array}$ & $\begin{array}{l}\text { 0.10** } \\
(0.01)\end{array}$ & $\begin{array}{l}8.05 * * \\
(0.27)\end{array}$ \\
\hline $\begin{array}{l}\text { Wife's age } \\
\text { squared } \\
\text { (in 100) }\end{array}$ & $\begin{array}{l}-\mathbf{- 0 . 0 1} * * \\
(\mathbf{0 . 0 2})\end{array}$ & $\begin{array}{l}-6.93 * * \\
(1.64)\end{array}$ & $\begin{array}{l}-0.01 * * \\
(0.01)\end{array}$ & $\begin{array}{l}-6.95 * * \\
(0.53)\end{array}$ & $\begin{array}{l}-0.03 * * \\
(0.01)\end{array}$ & $\begin{array}{l}-10.92 * * * \\
(1.26)\end{array}$ & $\begin{array}{l}-0.08 * * \\
(0.01)\end{array}$ & $\begin{array}{l}-17.02 * * \\
(0.74)\end{array}$ & $\begin{array}{l}-0.14 * * \\
(0.01)\end{array}$ & $\begin{array}{l}-11.10 \text { *** } \\
(0.37)\end{array}$ \\
\hline Children(0-4) & $\begin{array}{l}-\mathbf{- 0 . 0 4} * * \\
(0.02)\end{array}$ & $\begin{array}{l}-22.63 * * \\
(1.99)\end{array}$ & $\begin{array}{l}-0.07 * * \\
(0.008)\end{array}$ & $\begin{array}{l}-34.46^{* * *} \\
(0.68)\end{array}$ & $\begin{array}{l}-0.10 * * \\
(0.01)\end{array}$ & $\begin{array}{l}-34.59 \% * \\
(1.48)\end{array}$ & $\begin{array}{l}-0.14 * * \\
(0.01)\end{array}$ & $\begin{array}{l}-29.79 * * \\
(0.73)\end{array}$ & $\begin{array}{l}-\mathbf{0 . 1 1} * * \\
(0.01)\end{array}$ & $\begin{array}{l}-7.87 * * * \\
(0.32)\end{array}$ \\
\hline $\begin{array}{l}\text { Children } \\
(5-11)\end{array}$ & $\begin{array}{l}-\mathbf{- 0 . 0 1} * * \\
(\mathbf{0 . 0 1})\end{array}$ & $\begin{array}{l}-7.76 * * \\
(1.14)\end{array}$ & $\begin{array}{l}-0.02 * * \\
(0.005)\end{array}$ & $\begin{array}{l}-12.46 * * \\
(0.40)\end{array}$ & $\begin{array}{l}-0.05 * * \\
(0.01)\end{array}$ & $\begin{array}{l}-18.72 * * * \\
(1.07)\end{array}$ & $\begin{array}{l}-0.09 * * \\
(0.009)\end{array}$ & $\begin{array}{l}-20.19 * * \\
(0.60)\end{array}$ & $\begin{array}{l}-0.04 * * \\
(0.01)\end{array}$ & $\begin{array}{l}-3.18 * * \\
(0.30)\end{array}$ \\
\hline $\begin{array}{l}\text { Children } \\
(12-14)\end{array}$ & $\begin{array}{l}-\mathbf{- 0 . 0 0 1} \\
(0.02)\end{array}$ & $\begin{array}{l}-0.74 \\
(1.63)\end{array}$ & $\begin{array}{l}-0.005 * * \\
(0.007)\end{array}$ & $\begin{array}{l}-\mathbf{2 . 5 2} * * \\
(\mathbf{0 . 5 5})\end{array}$ & $\begin{array}{l}-\mathbf{0 . 0 3} * * \\
(0.01)\end{array}$ & $\begin{array}{l}-10.8^{* * *} \\
(1.50)\end{array}$ & $\begin{array}{l}-0.06 * * \\
(0.01)\end{array}$ & $\begin{array}{l}-13.38 * * \\
(0.89)\end{array}$ & $\begin{array}{l}-0.004 \\
(0.02)\end{array}$ & $\begin{array}{l}-0.49 \\
(0.47)\end{array}$ \\
\hline $\begin{array}{l}\text { Husband } \\
\text { primary grad. }\end{array}$ & $\begin{array}{l}-\mathbf{- 0 . 0 0 3} \\
(\mathbf{0 . 0 3})\end{array}$ & $\begin{array}{l}1.74 \\
(2.95)\end{array}$ & $\begin{array}{l}-\mathbf{- 0 . 0 1} * * \\
(\mathbf{0 . 0 3})\end{array}$ & $\begin{array}{l}-7.97 * * \\
(2.59)\end{array}$ & $\begin{array}{l}0.005 \\
(0.12)\end{array}$ & $\begin{array}{l}9.34 \\
(10.03)\end{array}$ & $\begin{array}{l}\text { 0.009 } \\
(0.13)\end{array}$ & $\begin{array}{l}4.28 \\
(9.20)\end{array}$ & $\begin{array}{l}0.04 \\
(0.34)\end{array}$ & $\begin{array}{l}-5.38 \\
(8.86)\end{array}$ \\
\hline $\begin{array}{l}\text { Husband } \\
\text { middle grad. }\end{array}$ & $\begin{array}{l}-\mathbf{0 . 0 2} * * \\
(0.05)\end{array}$ & $\begin{array}{l}-16.35 * * \\
(4.05)\end{array}$ & $\begin{array}{l}-\mathbf{- 0 . 0 2} * * \\
(\mathbf{0 . 0 3})\end{array}$ & $\begin{array}{l}-13.68 * * \\
(2.67)\end{array}$ & $\begin{array}{l}0.02 \\
(0.12)\end{array}$ & $\begin{array}{l}16.80 \\
(10.05)\end{array}$ & $\begin{array}{l}\mathbf{0 . 0 3} \\
(\mathbf{0 . 1 3})\end{array}$ & $\begin{array}{l}8.11 \\
(9.22)\end{array}$ & $\begin{array}{l}\mathbf{0 . 0 6} \\
(\mathbf{0 . 3 4})\end{array}$ & $\begin{array}{l}-1.80 \\
(8.86)\end{array}$ \\
\hline $\begin{array}{l}\text { Husband high } \\
\text { grad. }\end{array}$ & $\begin{array}{l}-0.04 * * \\
(0.05)\end{array}$ & $\begin{array}{l}-30.68 * * \\
(4.32)\end{array}$ & $\begin{array}{l}-0.04 * * \\
(0.03)\end{array}$ & $\begin{array}{l}-23.16 * * \\
(2.66)\end{array}$ & $\begin{array}{l}-0.0006 \\
(0.12)\end{array}$ & $\begin{array}{l}8.90 \\
(10.03)\end{array}$ & $\begin{array}{l}0.04 \\
(0.13)\end{array}$ & $\begin{array}{l}12.92 \\
(9.18)\end{array}$ & $\begin{array}{l}\mathbf{0 . 1 3 *} \\
(\mathbf{0 . 3 3})\end{array}$ & $\begin{array}{l}4.46 \\
(8.80)\end{array}$ \\
\hline $\begin{array}{l}\text { Husband } \\
\text { college grad. }\end{array}$ & $\begin{array}{l}-\mathbf{- 0 . 0 5 * *} \\
(0.10)\end{array}$ & $\begin{array}{l}-37.10 * * \\
(7.59)\end{array}$ & $\begin{array}{l}-\mathbf{- 0 . 0 7} * * \\
(\mathbf{0 . 0 3})\end{array}$ & $\begin{array}{l}-44.87 * * \\
(3.00)\end{array}$ & $\begin{array}{l}-0.05 * * \\
(0.12)\end{array}$ & $\begin{array}{l}-15.22 \\
(10.21)\end{array}$ & $\begin{array}{l}0.02 \\
(0.13)\end{array}$ & $\begin{array}{l}8.71 \\
(9.19)\end{array}$ & $\begin{array}{l}0.27 * * \\
(0.33)\end{array}$ & $\begin{array}{l}9.70 \\
(8.80)\end{array}$ \\
\hline $\begin{array}{l}\text { Other adults } \\
\text { in household }\end{array}$ & $\begin{array}{l}-\mathbf{- 0 . 0 0 8} \\
(0.03)\end{array}$ & $\begin{array}{l}-4.47 \\
(2.71)\end{array}$ & $\begin{array}{l}0.0008 \\
(0.01)\end{array}$ & $\begin{array}{l}1.42 \\
(0.82)\end{array}$ & $\begin{array}{l}0.01 * * \\
(0.02)\end{array}$ & $\begin{array}{l}7.97 \\
(1.80)\end{array}$ & $\begin{array}{l}\mathbf{0 . 0 4 * *} \\
(0.01)\end{array}$ & $\begin{array}{l}\text { 11.18** } \\
(1.10)\end{array}$ & $\begin{array}{l}\mathbf{0 . 0 6} * * \\
(0.03)\end{array}$ & $\begin{array}{l}\text { 3.66*** } \\
(0.72)\end{array}$ \\
\hline $\begin{array}{l}\text { Year } \\
\text { Dummies }\end{array}$ & Yes & Yes & Yes & Yes & Yes & Yes & Yes & Yes & Yes & Yes \\
\hline $\begin{array}{l}\text { Log } \\
\text { Likelihood }\end{array}$ & -5756 & -12575 & -73587 & -163510 & -14030 & -32725 & -36670 & -99647 & -19255 & -118543 \\
\hline Pseudo R2 & 0.05 & 0.02 & 0.05 & 0.02 & 0.05 & 0.02 & 0.04 & 0.01 & 0.06 & 0.01 \\
\hline $\mathbf{N}$ & 20126 & 20126 & 226193 & 226193 & 35714 & 35714 & 69480 & 69480 & 34668 & 34668 \\
\hline
\end{tabular}

Year dummies are included in all regressions. In probit regressions, marginal effects are reported ** indicates 1\% level of significance, *indicates $5 \%$ level of significance. 